\title{
VAT Refunds: A Review of Country Experience
}

Graham Harrison and Russell Krelove 



\title{
IMF Working Paper
}

Fiscal Affairs Department

\section{VAT Refunds: A Review of Country Experience}

\author{
Prepared by Graham Harrison and Russell Krelove ${ }^{1}$ \\ Authorized for distribution by Jean-Paul Bodin
}

November 2005

\begin{abstract}

\section{This Working Paper should not be reported as representing the views of the IMF.} The views expressed in this Working Paper are those of the author(s) and do not necessarily represent those of the IMF or IMF policy. Working Papers describe research in progress by the author(s) and are published to elicit comments and to further debate.
\end{abstract}

A key feature of the invoice-credit form of value-added tax (VAT) is that some businessesnotably exporters - will pay more tax on their purchases than is due on their sales, and so can seek refunds of excess credits from government. While refunding is straightforward in principle, serious problems arise in practice, including opportunities for fraud and corruption, and denial of refunds by governments with cash shortages. This makes the refund process the "Achilles heel" of the VAT. This paper examines the refund approaches of tax administrations in 36 developing, transitional, and developed countries. It evaluates the effectiveness of these approaches and suggests a model of best practice that takes into consideration compliance issues faced by countries during different stages of development.

JEL Classification Numbers: H25

Keywords: VAT, VAT refund, Refund claim, VAT audit

Author(s) E-Mail Address: gharrison@imf.org and rkrelove@imf.org

\footnotetext{
${ }^{1}$ The authors are particularly grateful to Jean-Paul Bodin and Michael Keen, chiefs of FAD’s Revenue Administration and Tax Policy divisions for their strong support and advice. They are also thankful to their other FAD colleagues who provided valuable assistance in conducting the VAT refund survey. Comments and documents provided by colleagues from the OECD have also been particularly helpful.
} 


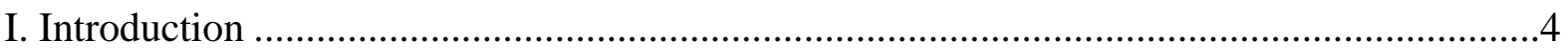

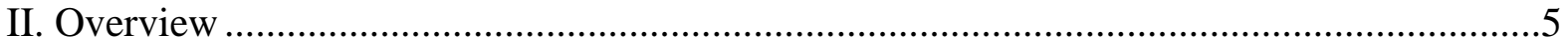

III. Country Experiences with VAT Refunds ...............................................................

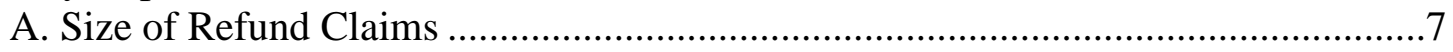

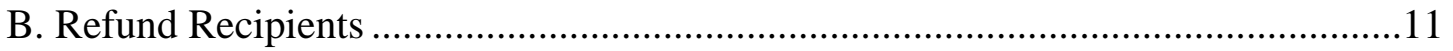

C. Time Taken to Process Refund Claims ...............................................................13

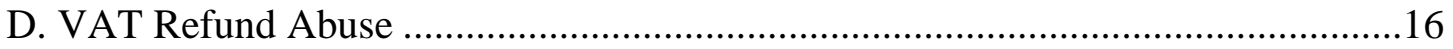

E. Cooperation Between Revenue Agencies ...........................................................18

F. Budgeting for VAT Refunds ........................................................................19

G. Organization and Management of VAT Refund Operations ................................19

IV. Administering VAT Refunds-Principles and Modern Practices.................................20

A. Administering VAT in a Self-Assessment Environment .....................................20

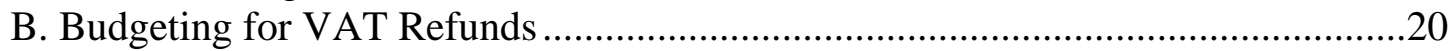

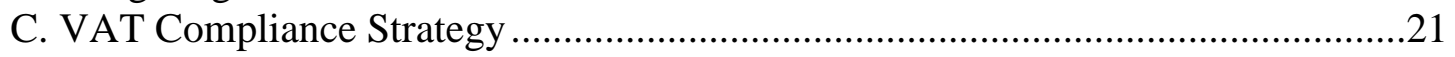

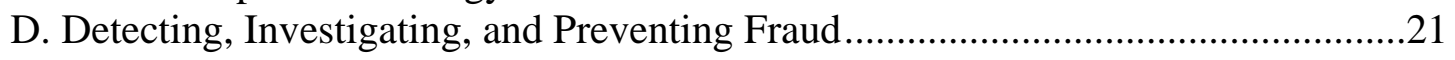

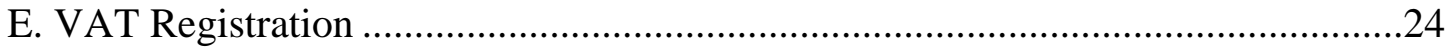

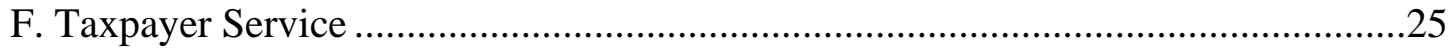

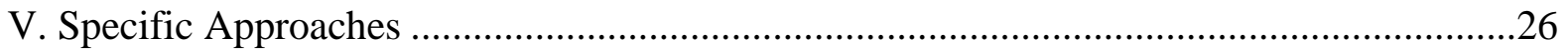

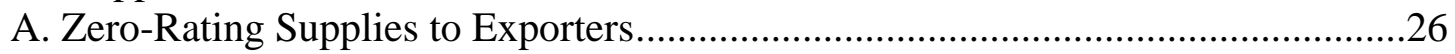

B. Large-Scale Cross-Checking of Invoices .......................................................27

C. Certification of Refund Claims by CPAs ..........................................................28

D. Preferential Treatment of Good Compliers ("Gold” Status Scheme) .....................28

E. Payment for Large Purchases Through the Banking System ..................................30

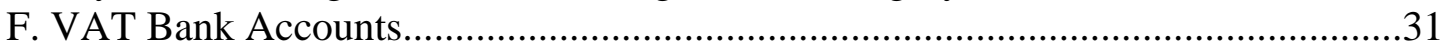

G. Deferring Accounting for VAT on Imported Capital Goods .................................33

H. Evaluation of Specific Approaches.....................................................................33

VI. Suggested Model of Best Practice ..........................................................................35

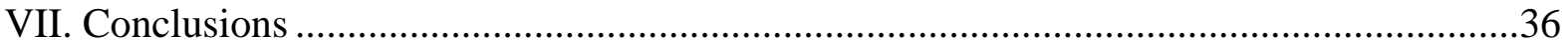

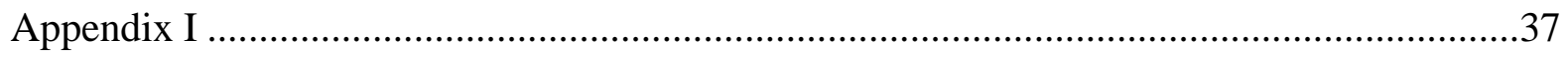

Tables

1. Value of VAT Refunds by Country/Region .....................................................................8

2. Value of VAT Refunds in Advanced, Transition, and Emerging Economies ......................9

3. Exporters' Share of Total VAT Refund Claims, 2001 ..................................................12

4. Estimate of VAT Revenue Losses in the United Kingdom in 2001-02 .............................17

5. Requirements to Qualify as a Gold and Silver Taxpayer ..............................................29

6. Summary Evaluation of Specific Approaches Against Performance Criteria .....................34 
Appendix Tables

A1. List of Countries that Responded to the IMF Survey ..................................................37

A2. Value of Refunds Paid in Percent of Gross VAT Collections, 1998-2001 ......................38

A3. Survey Responses I_All Countries .........................................................................39

A4. Survey Responses II-All Countries ....................................................................40

A5. Survey Responses III_All Countries..................................................................41

Figure 1. VAT Bank Account System ..........................................................................32

Boxes

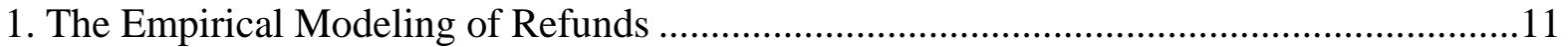

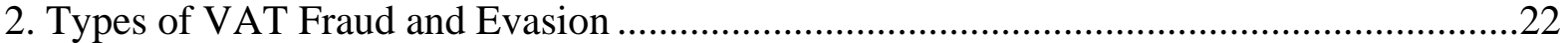

3. Description of Audit Types.....................................................................................24

4. Large-Scale Cross-Checking of Invoices-Korea and China .......................................27

5. Deferral Scheme for VAT Owing on Imported Capital Goods ........................................33 


\section{INTRODUCTION}

During the past two decades, the IMF's Fiscal Affairs Department (FAD) has provided substantial technical assistance in implementing and improving value-added tax (VAT) systems in developing and transitional countries. The VAT is now a key component of the tax system in over 130 countries at different stages of economic development, raising about 25 percent of the world's tax revenue. Building upon The Modern VAT, a study prepared in 2000-01 by a team of FAD economists to evaluate the IMF experience in relation to the VAT, ${ }^{2}$ this working paper follows up on a critical area of VAT administration-refunding VAT excess credits.

Experience with VAT implementation in many countries shows that refunding of credits has been the "Achilles heel" of the VAT. It has been a source of tension between tax authorities and the business sector and, in some countries, has led to complex administrative measures that have significantly undermined the functioning of the VAT system. This paper examines refund-related issues and suggests solutions. It is based on responses to a survey of tax administrations in 36 developing, transitional, and developed countries around the world. ${ }^{3}$

The survey requested information in four key areas: (1) general information on the VAT system operating in each country (e.g., registration threshold, VAT rates, items subject to zero-rating, and number of VAT payers); (2) details of each country's VAT refund system (e.g., statutory provisions relevant to the treatment of excess VAT credits, categories of refund recipients, number and size of refund claims, procedures followed by refund claimants, organizational arrangements for processing VAT refunds, and specific regimes introduced to counter administrative problems); (3) specific data relating to tax audits and identification of cases of refund fraud; and (4) evaluation and comments on the efficiency and effectiveness of the VAT refund system, including proposals for improvement.

After an overview (Section II), the paper outlines country experiences with VAT refunds (Section III). It then examines key principles and modern practices in administering VAT refunds (Section IV), and evaluates the effectiveness of various specific approaches adopted by a range of countries (Section V). Finally, the paper suggests a model of best practice that takes into consideration compliance and environmental issues typically faced by countries during different stages of transition and development (Section VI). Conclusions are then given (Section VII).

\footnotetext{
2 The Modern VAT, Ebrill, Keen, Bodin, and Summers (IMF, 2001).

${ }^{3}$ Appendix Table A1 provides a list of respondents. Some countries classified throughout the paper as "Eastern European” countries have, since the time of the IMF survey, joined the EU.
} 


\section{OVERVIEW}

A key feature of the invoice-credit form of VAT is that some businesses will pay more VAT on their purchases than they collect on the taxable sales they make, and so should be able to reclaim the difference from the tax authorities. This is particularly true of exporters whose export sales are zero-rated. ${ }^{4}$ It is also true of businesses-particularly new enterprises - that make large purchases relative to current sales. Refunds can be substantial. In many countries, VAT refund levels exceed 40 percent of gross VAT collections. ${ }^{5}$ Forty percent of the survey respondents repay a third or more of gross VAT collections in refunds. Countries with refund levels below 20 percent are mostly in Africa, Asia, and Latin America.

In theory, VAT refunds should be paid promptly following receipt by the tax authority of a VAT return giving rise to an excess credit. That is the practice of most developed countries, where refunds are generally paid within four weeks of a refund claim being made. The situation is different in developing and transitional countries, however, where it often takes several months, and sometimes more than a year, to process refund claims. In export-oriented countries, such practices can seriously undermine the competitiveness of the export sector.

The prevalence of fraudulent claims is often cited by tax officials as a major reason for delaying payment of refunds. Often, less advanced tax administrations pursue timeconsuming and labor-intensive processes to verify claims before approving refunds, resulting in backlogs of refund requests and considerable disquiet among business taxpayers who have been deprived of their working capital. In contrast, the most effective and efficient tax administrations tackle refund-related fraud as part of a broader VAT compliance strategy based on risk management principles, and generally limit pre-refund verification checks to perceived high-risk claims.

Delays in processing refunds also occur when state budgets are under pressure, and when tax collection targets are not being met. This often happens when tax authorities and finance ministries do not have suitable forecasting and monitoring systems in place to anticipate refund levels, and do not set aside sufficient funds to meet legitimate refund claims when they occur. Administrations with more sophisticated forecasting and budgeting capabilities have been able to predict refund levels with a fair degree of precision, given that a pattern of refund claims tends to develop within countries over time.

When tax authorities deny payment of legitimate refund claims, the nature of the VAT is effectively altered, in part, from a tax on final consumption to a tax on production. To avoid

\footnotetext{
${ }^{4}$ The VAT systems of most countries apply a destination principle, by which total VAT revenue in relation to a good accrues to the country in which final consumption takes place. Application of this principle therefore requires VAT to be removed from exports. This is achieved by applying a zero-rate to export sales, and allowing the exporter to recover VAT paid on purchases. Only in this way will goods be dispatched from a country free of VAT.

${ }^{5}$ VAT refund levels (in percent of gross VAT collections) are especially high in developed countries and the most advanced transitional economies (e.g., the United Kingdom, the Netherlands, Sweden, Canada, Singapore, Russia, Latvia, Slovak Republic, Hungary, and South Africa).
} 
this happening, VAT policymakers often advocate that the same tight statutory timetables imposed on persons paying VAT should also apply to tax authorities in refunding VAT. It is of little surprise, therefore, that 90 percent of the countries that responded to the IMF survey reported that their tax authorities are bound by law to making refunds within a prescribed timeframe, generally 30 days.

Some countries (around 40 percent of those surveyed) go further, with their laws providing for interest to be paid on late refunds - this recognizes that excess credits not returned promptly to the taxpayer are tantamount to funds loaned to the government. At the same time, policymakers acknowledge that safeguards need to be in place to tackle fraudsters who take advantage of regimes providing prompt VAT refunds. Safeguards range from providing tax officials with statutory powers to conduct audits and verification checks, to measures such as requiring security or bank guarantees from traders who seek refunds. In 60 percent of the surveyed countries, mandatory carry-forward periods for excess VAT credits are also imposed, generally for nonexporters, to limit the number of refund claims.

Notwithstanding the preponderance of statutory time limits for making refunds, experience is that these are often insufficient in guaranteeing that timely refunds will be made in practice. Many examples exist where tax authorities do not meet processing deadlines, and while this is more likely to be the case in developing and transitional countries, it is not confined to them. It is not uncommon for business enterprises in advanced economies, also, to complain about the time taken by tax administrations to refund amounts due to them.

Various approaches have emerged in an attempt to reduce the number of refund claims and address business cash-flow concerns. Some EU countries (e.g., France and Ireland), as well as countries in North Africa and Asia, have implemented schemes that apply a zero-rate on supplies to exporters. In addition, a number of countries have special arrangements in place to deal with excess credits associated with imported capital goods. For example, a few countries provide VAT exemptions for investors who import heavy equipment, while others have opted for a system that defers the payment of VAT owing on the imported capital items. While the perceived benefits of these arrangements may be tempting, they also add complexity to administration and present new revenue risks-both of which should be carefully considered if introduction of these measures is contemplated.

With the aim of further shielding the VAT system from refund abuse, and controlling taxpayer behavior, some countries (e.g., Azerbaijan, Bulgaria, China, and Korea) have attempted to cross-check vast quantities of purchases and sales transaction data. With similar objectives in mind, Bulgaria requires its business enterprises to deposit the VAT due on their supplies into special bank accounts (thereby locking away a portion of the enterprises' working capital). A distinguishing feature of these schemes is that they subject registered businesses to additional compliance costs, and therefore raise questions about the extent to which the business sector should be expected to bear the costs of tax administration.

Another approach adopted by countries with large shadow economies (e.g., Azerbaijan), has been to simply deny VAT credits on large purchases where payment is made in cash (i.e. under the law, VAT taxpayers are entitled to input tax credits only where payment has been made through the banks). Of interest, also, is Kenya's requirement that all large refund 
claims must be certified by registered CPAs. This scheme, in effect, outsources the refund verification function to accounting professionals, and thereby raises for discussion the scope of their role in VAT administration.

Finally, in response to increasing demands by the business community for improved services from tax administrations, there has been a growing trend to introduce fast-track refund processing for taxpayers with proven records of good compliance.

\section{COUNTRY EXPERIENCES WITH VAT REFUNDS}

This section examines the key findings of the survey, including the following:

$\checkmark$ Refunds can be substantial, both in absolute terms and as a percentage of VAT collections.

$\checkmark$ Refund levels vary widely from region to region.

$\checkmark$ Refund levels are typically higher in advanced and emerging economies.

$\checkmark$ Within regions, refund levels are largely similar among countries with similar VAT systems and economic conditions.

$\checkmark$ A pattern of refund claims tends to develop within countries over time, with refund levels being relatively constant from year to year.

$\checkmark$ Not surprisingly, refund claims are dominated by exporters.

$\checkmark$ Notwithstanding that most countries have statutory deadlines for making refunds, these are often not met by tax authorities.

$\checkmark$ The VAT laws of more than half the countries surveyed do not provide for interest to be paid on late refunds.

$\checkmark$ All countries report VAT refund abuse, but most have difficulty in estimating the scale of associated revenue losses.

$\checkmark$ While the nature of VAT refund abuse is similar across countries, the environment in which it occurs and the approaches to counteract it vary between countries.

$\checkmark \quad$ VAT refund abuse is only one component of VAT fraud. A number of tax administrations focus their audit resources mainly on VAT refunds and do not pay adequate attention to other risks of VAT fraud and evasion.

\section{A. Size of Refund Claims}

Refunds can be substantial. As shown in Table 1, the amount of VAT refunds as a percentage of gross VAT collections averages 30 percent or more in half the regions surveyed. In some economies (e.g., Slovak Republic and Canada), refund levels exceed 
50 percent of gross VAT collections, while in others (e.g., Sweden, the Netherlands, Russia, United Kingdom, Hungary, and South Africa) they reach levels of at least 40 percent (Table 2).

Table 1. Value of VAT Refunds by Country/Region

(In percent of gross VAT collections)

\begin{tabular}{lc}
\hline & Average $^{1}$ \\
\hline Canada & 50.3 \\
EU & 38.1 \\
Eastern Europe & 36.8 \\
New Zealand & 35.5 \\
Former Soviet Union countries & 29.6 \\
Latin America & 17.4 \\
Middle East & 16.2 \\
Asia (not including Singapore) & 7.0 \\
Africa (not including South Africa) & 6.0 \\
\hline
\end{tabular}

Sources: IMF survey responses, IMF staff estimates, and World Economic Outlook.

${ }^{1}$ Average refund level over a four-year period (1998 to 2001).

\section{Refund levels vary from region to region, and are highest in advanced, transitional, and} emerging economies. Table 2 illustrates the variation in amounts refunded across the surveyed countries, grouped according to stages of economic development. The value of refunds (in percent of gross VAT collections) is highest in EU countries, Eastern Europe, Canada, New Zealand, and Russia. Within regions, refund levels are largely similar among countries with similar VAT systems and economic conditions. In the EU, for example, refund levels tend to be in the 40 to 50 percent range, with the exception of France and Ireland, whose refund levels are influenced by their practice of zero-rating supplies to exporters (discussed in Section V). Refund levels are generally low (less than 20 percent, and often below 10 percent, of gross VAT collections) in Africa, Asia, and Latin America.

What determines the level of refunds? A country's VAT refund level (in percent of gross VAT collections) is influenced by a number of factors, including (1) the nature of the economy (e.g., extent to which investment generates excess VAT credits, value-added of export industries, and proportion of taxable and zero-rated sales in the economy); (2) the design of the VAT system, particularly the extent of zero-rating and use of multiple rates; (3) taxpayer compliance behavior and extent of VAT fraud; and (4) the system and culture of the tax administration (e.g., level of corruption, capacity to detect and prevent VAT fraud, and commitment to taxpayer service in meeting statutory payment deadlines).

Everything else equal, the level of VAT refunds is likely to be higher in countries with more open and faster-growing economies (i.e. where there are higher export and investment shares in total economic activity), as well as in countries with modern tax systems and administration that apply self-assessment procedures and respect taxpayers' rights, including minimizing tax compliance costs. Conversely, refunds will be lower where countries have adopted specific schemes to reduce the number and size of refund claims-these schemes are 
discussed in Section V, and include such measures as zero-rating supplies to exporters, and deferring VAT liabilities on imported capital equipment. Finally, refund levels will also be lower in countries where tax administrations and treasuries deny refund claims during periods of government cash shortages.

Table 2. Value of VAT Refunds in Advanced, Transitional, and Emerging Economies ${ }^{1}$

(In percent of gross VAT collections)

\begin{tabular}{|c|c|c|c|c|c|c|c|}
\hline \multicolumn{2}{|c|}{ Advanced Economies } & \multicolumn{2}{|c|}{ Transitional Economies } & \multicolumn{2}{|c|}{ Emerging Economies } & \multicolumn{2}{|l|}{ Others } \\
\hline Canada & 50.3 & Bulgaria & 21.5 & Chile & 28.8 & Algeria & 24.3 \\
\hline France & 21.2 & Hungary & 48.2 & Colombia & 4.1 & Bolivia & 10.4 \\
\hline Ireland & 24.9 & Latvia & 49.1 & Indonesia & 12.4 & Cambodia & 2.8 \\
\hline Netherlands & 50.0 & Romania & 24.7 & Mexico & 32.1 & Cameroon & 8.8 \\
\hline New Zealand & 35.5 & Russia & 44.6 & Morocco & 5.1 & El Salvador & 9.6 \\
\hline Sweden & 48.6 & Slovak Rep. & 53.9 & Peru & 19.8 & Kenya & 7.2 \\
\hline United Kingdom & 40.9 & Ukraine & 24.1 & South Africa & 39.5 & Mozambique & 2.7 \\
\hline
\end{tabular}

Sources: IMF survey responses, IMF staff estimates, and World Economic Outlook.

${ }^{1}$ Average refund level over a four-year period (1998 to 2001).

A pattern of refund claims tends to develop within countries over time. Table A2 in the Appendix illustrates how refund levels within countries tend to be constant, with some minor variations, from year to year. FAD's experience is that each country develops a pattern of refund claims over time, influenced by the factors discussed above (e.g., characteristics of the economy, and structure of the VAT system). It is important for tax administrations to have a sense of the level of refunds they might reasonably expect to pay, both for resource planning and budgetary purposes, and as a warning sign of attempted fraud.

What is a reasonable level of refunds? In a simple economy where the tax administration pays VAT refund claims promptly, refunds as a proportion of gross VAT revenue under a fully functioning, single-rate, VAT would be

$$
(\alpha I+\beta(1-\lambda) Z) / \tilde{e}
$$

where: $I$ and $Z$ denote the shares of investment and zero-rated items (including exports) in GDP; $\alpha$ is the proportion of investment that generates excess credits (a quantity one would expect to be higher in faster-growing economies); $\beta$ is the proportion of zero-rated sales that generates excess credits (and would be larger to the extent that sellers of zero-rated goods do not also supply taxable goods); $\lambda$ is the ratio of value added to sales in the zero-rated sector; and $\tilde{e}$ is the gross efficiency ratio (gross VAT collections as a percent of GDP per percentage point of tax). ${ }^{6}$ This expression gives precise expression to the general observations above that

\footnotetext{
${ }^{6}$ See The Modern VAT, p. 158. This expression is an identity in the simple world hypothesized, and follows
} directly from the fact that the level of refunds is the sum of refunds generated by tax paid on Investment 
refunds will be higher: (1) in faster-growing economies (both because investment will be higher and more of it is likely to be by new firms with no output tax against which to offset credits); and (2) in more open economies. Both of these effects are supported by the empirical work reported in Box $1 .^{7}$

This formula can be used to make simple calculations of a reasonable level of refunds. Suppose that one is considering an economy in which the investment ratio is 10 percent, and exports account for 40 percent of GDP. ${ }^{8}$ Assuming that 5 percent of investment generates excess credits, that value-added is 40 percent of sales in the export sector, and that exporters do not supply significant amounts in the domestic market (so that $\beta=1$ ), then achieving a gross efficiency ratio of 0.9-about the average for both transitional countries and emerging markets in the sample-will imply paying refunds equal to 27 percent of gross collections. ${ }^{9}$

These calculations assume, however, a simply designed and perfectly administered VAT. A complementary approach is to explore, instead, how observed levels of refund vary in practice with aspects of tax design and features of the wider economy. Box 1 reports on an exercise of this kind. This can be used to estimate the level of refunds which, though not necessarily optimal, matches experience in other countries. For example, consider a country with high levels of literacy, and with exports equal to 30 percent of GDP, and GDP growth of 3 percent, and with a single nonzero VAT rate. Then the estimated equation in Box 1 predicts that refunds would constitute about 37 percent of gross collections if refunds are paid through budget appropriation, and about 41 percent if refunds are paid out of revenue.

According to the equation, these ratios fall to about 12 percent and 16 percent if supplies to exporters are zero-rated (D1 $=1$ ), which is a significant impact. Similarly, these ratios fall to 20 percent and 24 percent where the country exhibits characteristics similar to those of the countries appearing in the last column of Table $2(\mathrm{D} 3=1)$. Again, the impact on the ratio is large in this case.

expenditures (equal to $\alpha I^{*} G D P$ ) and the refund of tax paid on inputs into the production of zero-rated exports $\left(\beta(1-\lambda) Z^{*} G D P\right)$, and some straightforward manipulation. The gross efficiency ratio $\tilde{e}$ is similar to the VAT efficiency ratio (see The Modern VAT, pp. 40-43) except that it gives gross VAT revenue raised as a share of GDP per percent of VAT tax rate, before payment of refunds.

${ }^{7}$ The equation assumes a perfectly administered VAT. The empirical work in Box 1 takes into account real world complications - including actual refund procedures used, and the structure of the economy - that have been abstracted from in the equation. For example, the equation assumes that those firms that make zero-rated supplies do not also make taxable supplies in appreciable amounts. The actual survey data (and the estimated coefficients) would reflect these considerations.

${ }^{8}$ For the survey countries, exports average about 35 percent of GDP, and private investment about 16 percent.

${ }^{9}$ For the survey countries, the gross efficiency ratios range by about a factor of 10 , from a low of 22 percent (Algeria) to a high of 209 percent (New Zealand). This variability much exceeds the variability across sample countries in export and investment ratios. 


\section{Box 1. The Empirical Modeling of Refunds}

Using the data from the survey and other macroeconomic and social variables from the survey countries, a number of cross-section linear regressions were run to model the level of refunds. A preferred estimated equation is the following:

$$
\begin{aligned}
& \text { Refunds }=0.16 \text { Exports }+.75 \text { Growth }+.19 \text { Literacy + .90 Range }-25.3 \text { D1 + 3.8 D2 - 17.5 D3 , } \\
& \begin{array}{lllllll}
(2.06) * & (0.69) & (3.41)^{*} & (2.6)^{*} & (-2.51)^{*} & (0.83) & (-3.70)^{*}
\end{array}
\end{aligned}
$$

where t-ratios are reported in parentheses and an asterisk denotes significance at 5 percent; the adjusted $\mathrm{R}$-squared is 0.8826 . In this equation, Refunds is the average of the refunds paid to gross VAT collections over the survey period 1998-2001, while Exports represents the share of exports in GDP (in percent); Growth is average GDP growth rate over the survey period (in percent); Literacy is the literacy rate (in percent); Range is the difference between the highest and lowest (nonzero) VAT rates (in percent); and D3 is a dummy taking the value unity for the "other" economies in Table 2, which are developing countries that are neither transitional nor emerging, and are outliers in the sample in that, in general, they are characterized by weak refund performance. In the equation there are two other dummy variables representing characteristics of the refund regime: D1 takes on the value 1 if supplies to exporters are zero-rated; and D2 takes on the value of 1 when refunds are paid from gross collections (rather than as an expenditure appropriation).

As expected, refunds rise with the openness of the economy (exports) and fall with less mature tax administrations (other); these variables are significant at the 5 percent level. Growth also has a positive effect on the refund ratio, as expected-perhaps reflecting special treatment of tax liability on purchases of capital goods - although the coefficient is not significant. The impact of literacy is positive and significant, capturing the development of the economy, ${ }^{10}$ as is the range or VAT rates, capturing refunds generated on domestic sales at preferential rates. Zero-rating supplies to exporters (D1) lowers the refund ratio, as expected. Interestingly, paying refunds out of general revenue (D2) has a positive effect on refunds (though not significant in this equation, the positive sign is robust across a variety of specifications), implying that using explicit budgetary appropriations for VAT refunds actually has a retarding effect on refund payments.

\section{B. Refund Recipients}

Refund claims are dominated by exporters. Table 3 shows that most VAT refund claims are made by exporters, both in number and value of claims. ${ }^{11}$ In many countries, VAT laws limit entitlement to refunds to exporters, requiring other (nonexporting) enterprises to carry forward their excess credits to subsequent tax periods - see later discussion of mandatory carry-forward schemes. Typically, a small number of large exporters account for the majority of VAT excess credits refunded.

\footnotetext{
${ }^{10}$ Literacy was also an important variable in explaining VAT revenue collections across countries, as was the range of rates; see The Modern VAT, p. 45.

${ }^{11}$ Complete data on exporters' share of total VAT refund claims is limited to the countries listed in Table 3.
} 
Table 3. Exporters’ Share of Total VAT Refund Claims, 2001

(In percent of total claims)

\begin{tabular}{lcc}
\hline & $\begin{array}{c}\text { Share in Number of } \\
\text { Claims } \\
\text { to Total Claims }\end{array}$ & $\begin{array}{c}\text { Share in Value of Claims } \\
\text { to Total Claims }\end{array}$ \\
\hline $\begin{array}{l}\text { Africa } \\
\text { Cameroon }\end{array}$ & 60 & 66 \\
$\begin{array}{l}\text { Kenya } \\
\text { Morocco }\end{array}$ & 70 & 48 \\
$\begin{array}{l}\text { Asia } \\
\text { Cambodia }\end{array}$ & 80 & 80 \\
$\begin{array}{l}\text { Europe } \\
\text { Slovak Republic }\end{array}$ & 76 & \\
$\begin{array}{l}\text { Former Soviet Union } \\
\text { Kazakhstan }\end{array}$ & 56 & 41 \\
$\begin{array}{l}\text { Latin America } \\
\text { Bolivia }\end{array}$ & 100 & 63 \\
Chile & & \\
Colombia & & 100 \\
El Salvador & 100 & 100 \\
Peru & 64 & 89 \\
\hline
\end{tabular}

Source: IMF survey responses.

The balance of other refund claimants (i.e. nonexporters) tend to fall into the following groups:

$\checkmark$ Registered taxpayers supplying zero-rated goods and services to the domestic market (e.g., hospitals and universities in Australia, where supplies of health and education services are zero-rated).

$\checkmark$ Registered traders whose excess credits arise from temporary trading conditions-a seasonal slump in sales can result in a temporary credit balance. Many countries require the taxpayer to carry forward excess credits for a certain period (e.g., three or six months) knowing, in all likelihood, that these credits will be offset by future VAT liabilities.

$\checkmark$ Registered entities that have made large purchases of capital goods relative to current sales - it is not uncommon for a start-up enterprise, for example, to make major investments in heavy equipment several months before commencing trading. Established businesses may also experience periods where VAT paid on large purchases (e.g., replacement machinery) exceeds VAT payable on taxable sales.

$\checkmark$ Registered traders subject to a dual rate structure-refund claims arise when outputs are taxed at a reduced rate while inputs are taxed at the higher standard VAT rate. While data relating to this category of refunds are sparse, the limited information collected from the survey suggests that refunds of this kind are minimal. About a third of the countries surveyed reported that they use multiple rates. Of these, it would appear that the 
Slovak Republic's experience-with refund levels for this category at around 7 percent by number, and 15 percent by value, of total claims in 2001-is toward the upper end of the scale.

$\checkmark$ Registered traders subject to withholding arrangements — some countries, particularly in Latin America and West Africa, require certain business and government entities to withhold amounts of VAT from payments to their suppliers. These schemes have several drawbacks: in particular, refund claims can proliferate under these arrangements, especially if withholding rates are set too high.

$\checkmark$ Claimants not registered for VAT - these include: (1) diplomats and other bodies exempted from VAT (and other taxes) under diplomatic conventions and international agreements; and (2) visiting tourists, who, in some countries, are entitled to refunds of VAT on purchases that they take home with them (i.e. the goods are effectively being exported). Refunds to tourists may be limited to large purchases made within a specified time before departure.

\section{Time Taken to Process Refund Claims}

Most countries have statutory deadlines for payment of VAT refunds. A common feature of VAT laws is to impose a deadline on the tax authority to pay refunds within a prescribed period starting from the time a claim for a refund is made. Policymakers have often advocated that, to make the operation of the VAT fair, the same tight statutory timetables imposed on persons paying VAT should also apply to tax authorities refunding VAT. Another argument in support of statutory deadlines is that they help reduce corrupt practices, the rationale being that if the law requires prompt refunding (and this is properly enforced), tax officials will have less opportunity to extract payments from traders in return for speeding up refunds (or indeed paying them at all). ${ }^{12}$

It is of no surprise, therefore, that 90 percent of survey respondents (see Table A3 in the Appendix) report that their tax authorities are required to make refunds within a prescribed timeframe, ranging from 24 hours (as in the case of Peru, where security is provided by the claimant) to 90 days (in France). ${ }^{13}$ The most common statutory period for making refunds is 30 days (40 percent of the survey countries have a 30-day refund period).

Tax officials invariably argue that overly tight deadlines place them at a disadvantage in dealing with evasion and fraud because they need sufficient time to monitor claims and conduct verification checks on suspect cases. In setting deadlines, it is therefore necessary to strike a balance between the time needed by authorities to safeguard the system and the time standards that are acceptable to the trade community. In addition to statutory deadlines, some

\footnotetext{
${ }^{12}$ Anecdotal evidence in some developing countries suggests the existence of a widely known price for obtaining refunds (e.g., 5 percent of the amount refunded).

${ }^{13}$ While the French VAT code stipulates a timeframe of 90 days, the authorities apply an administrative performance standard of making refunds within 30 days.
} 
tax authorities reinforce their commitment to timely refund processing by publishing service standards in taxpayer charters and similar public documents.

Statutory deadlines are often not met. Despite the preponderance of statutory time limits and administrative performance standards, experience is that these are often insufficient in guaranteeing that timely refunds will be made. This may be due to weaknesses in the refund processing system, or because the government faces short-term cash shortfalls.

There are many examples where tax authorities do not meet processing deadlines, and while this is more likely to be the case in developing and transitional countries, it is not confined to them. It is not uncommon for business enterprises in advanced economies, also, to complain about the time taken by tax administrations to refund amounts due to them.

Taxpayers are often entitled to interest on refunds paid late. In around 40 percent of the countries surveyed, VAT laws provide for interest to be paid on late refunds. De minimus rules may apply (e.g., in Singapore and the United Kingdom, no interest is payable if the interest calculation is less than a prescribed statutory amount). Payment of interest is seen as compensation to taxpayers who, in essence, have loaned funds to the government. Interest is calculated at a statutory rate-often aligned to prevailing commercial bank interest rates, and adjusted quarterly or half-yearly by regulation-multiplied by the number of days elapsed since expiration of the statutory deadline.

Many VAT systems impose a mandatory carry-forward period for excess VAT credits. To reduce the number of refunds and opportunities for abuse, 60 percent of surveyed countries require taxpayers, particularly nonexporters, to carry forward their excess VAT credits for a specified period. A refund is paid only if an amount of excess credit remains to be recovered by the taxpayer at the end of the carry-forward period. The rationale of the carry-forward scheme is that, for a nonexporting business, an excess VAT credit in one tax period should normally be followed by periods where net VAT liabilities are sufficient to absorb the credit brought forward. As a general rule, carry-forward measures are not applied to regular exporters, given that a business that exports most of its products will consistently have excess VAT credits that are unlikely to be absorbed by VAT liabilities in subsequent tax periods.

Carry-forward periods range from 30 days to more than a year, but are generally in the range of three to six months. The EU's Sixth Directive leaves the decision on the means of dealing with excess VAT credits to the discretion of the country: "Member States may either make a refund or carry the excess forward to the following period according to conditions which they shall determine." ${ }^{14}$ One EU survey respondent (France) reported that it is the norm for excess VAT credits to be carried-forward for nonexporters, with refunding being the exception.

Others (Ireland, the United Kingdom, Sweden, and the Netherlands) reported that they do not have mandatory carry-forward periods for VAT credits. Table A3 in the Appendix provides further details.

\footnotetext{
${ }^{14}$ European Community, Sixth Council Directive, Article 18 (4).
} 
Carry-forward measures are not welcomed by firms that make large investments in heavy equipment prior to beginning operations. Having to wait long periods to recover VAT can add substantially to their costs. To overcome this problem, some countries (e.g., Albania) allow businesses to defer their VAT liabilities on certain imported capital goods. This scheme is discussed in Section V.

Many VAT systems allow for refunds to be offset against other tax liabilities. VAT laws in 80 percent of the surveyed countries allow tax authorities to offset VAT refunds against other tax debts (e.g., income tax) owed by the taxpayer (i.e., the amount due for refund may be used, with or without the taxpayer's consent, to pay off the taxpayer's other tax debts). ${ }^{15}$ It is a condition in some countries that a tax liability must be due and payable before VAT excess credits can be offset against it. For others, VAT refunds can be offset against other tax liabilities even though the amounts are not yet due for payment. In some countriesparticularly member states of the former Soviet Union-VAT refund offsetting may extend beyond the realm of tax liabilities to include nontax debts owing to the state. Revenue administrations in Canada and Hungary have legal authority to offset excess VAT credits against customs duties as well as other tax liabilities.

Offsetting may be mandatory under the law, or subject to the discretion of the tax authority. In Australia, a limited discretion in the tax laws essentially allows the tax office to refund (rather than offset) VAT excess credits in situations where the taxpayer has other tax liabilities only where: (1) the tax debt is not yet payable; (2) the tax debt is subject to an arrangement to pay by installments; or (3) recovery of the tax debt is deferred (e.g., where a tax assessment is in dispute and subject to adjudication by the courts).

In providing technical advice to tax administrations across a wide range of countries, FAD has supported the general principle of offsetting, on grounds that it is consistent with sound debt management practice. FAD has, however, qualified its advice in three areas. First, VAT refunds should be offset only against other tax liabilities. It is administratively cumbersome to apply excess VAT credits to nontax debts owing to the state. Second, as a general rule, VAT refunds should not be offset against anticipated tax liabilities (i.e., taxes assessed but not yet due for payment), given the negative effect that this offsetting may have on a taxpayer's cash flow. However, if a taxpayer has a history of noncompliance (including failure to file income tax returns or pay amounts when due, or engages in other activities to avoid meeting tax obligations), the tax authority may consider offsetting even though amounts are not yet due for payment. Third, offsetting should be adopted only if a tax authority has established an adequate taxpayer accounting system and debt management infrastructure. ${ }^{16}$

\footnotetext{
${ }^{15}$ In some countries, legal authority to offset may also be provided under general law principles, as well as under tax statutes.

${ }^{16}$ Modern unified tax administrations (i.e. where a single unified administration collects all domestic tax liabilities, including VAT and income tax—see The Modern VAT) have implemented integrated computerized accounting systems to provide a consolidated view of a taxpayer's liabilities and entitlements across all taxes.
} 
Without appropriate systems in place, tax authorities have great difficulty in practice administering offset arrangements. Unless the accounting and receivables management systems of a tax administration provide a consolidated up-to-date view of a taxpayer's liabilities and entitlements across all taxes, mixing the liabilities and collection of separate taxes should be approached with caution.

Sometimes, small claims are not accepted. To ease demands placed on the tax administration, three respondents (Italy, France, and Peru) reported that refund claims are not processed for amounts below a specified threshold.

Some countries have denied payment of all refund claims. In an effort to wipe the slate clean of large backlogs of refund claims, at least two countries in Africa are understood to have taken the extraordinary step of enacting legislation to deny all outstanding claims as at a specified date. This practice has serious long-term consequences for the integrity of the tax system and the credibility of the tax administration.

\section{VAT Refund Abuse}

A large amount of VAT revenue is lost as a result of VAT refund abuse. Registered taxpayers may not pay the correct amount of VAT for a number of reasons including error, deliberately understating their VAT liabilities, or through systematic attacks on the VAT refund system. While countries have generally found it difficult to estimate the size of the revenue leakage, it is thought to be substantial. Some countries have made progress in recent years in estimating the scale of losses on VAT, in particular the United Kingdom, where the authorities have estimated the amount of VAT losses to be around 15.8 percent of net VAT receipts in 2002-03, made up of fraud and nonfraud losses. ${ }^{17}$ Table 4 shows U.K. estimates periods for different areas of loss for 2001-02.

\footnotetext{
${ }^{17}$ In 2002-03, U.K. VAT receipts were $£ 108.8$ billion, of which $£ 45.2$ billion was refunded (source: Tackling VAT Fraud, report of the U.K. National Audit Office, March 2004).
} 
Table 4. Estimate of VAT Revenue Losses in the United Kingdom in 2001-02

\begin{tabular}{lc}
\hline \multicolumn{1}{c}{ Area of Revenue Loss } & Estimate (in $£$ billion) \\
\hline $\begin{array}{l}\text { Noncompliance by traders in paying the right amount of VAT at the right time, } \\
\text { because of genuine mistakes or where they deliberately understate a portion of } \\
\text { their sales or falsely inflate the value of purchases to reduce their VAT liability. }\end{array}$ & 2.5 to 4.0 \\
VAT “missing trader” fraud where fraudsters register for VAT, buy goods & 1.77 to 2.75 \\
VAT-free from another EU member state, sell them on at VAT inclusive prices & \\
and then disappear without paying the VAT due to the tax authority. & 0.4 to 0.5 \\
Traders failing to register to pay VAT where their turnover exceeds the \\
registration threshold. Some may operate in the shadow economy not knowing of \\
the requirement to register. \\
VAT avoidance schemes that businesses purport to be legal, but are (or are likely \\
to be) challenged by the tax authority. \\
Total
\end{tabular}

Source: Tackling VAT Fraud, report of the U.K. National Audit Office, March 2004.

The table does not isolate losses directly attributable to refund-related fraud, but does give a context for where refund abuse fits in to losses overall. Of note, during 2002-03, the U.K. authorities disallowed $£ 63$ million of VAT refunds to exporters suspected of being part of a supply chain where VAT had gone missing through a "carousel" fraud (a type of "missing trader" fraud-see Box 2 in Section IV for a description of the various types of fraud and evasion encountered by countries administering VAT).

The nature of VAT fraud and evasion is similar across countries, but the methods used to tackle it may differ. Countries employ a range of methods to address refund abuse and VAT evasion. The principal methods are examined in detail in Sections IV and V. Some countries (e.g., Hungary, New Zealand, and the United Kingdom) apply methods grounded in risk management principles, while others (e.g., Azerbaijan, Bulgaria, China, and Korea) seek to influence or control taxpayer behavior through more intrusive systems and regulations applied to all VAT taxpayers, good and poor compliers alike.

Experience shows that tax authorities in a number of transitional and developing countries have often shown reluctance to embrace, fully, risk management approaches to processing VAT refunds. The authorities are simply not convinced that these methods provide adequate safeguards in environments where there is a weak culture of paying taxes. For this reason, tax administrations in these environments continue to pursue approaches designed to exercise tight control over taxpayers and their transactions. This is discussed further in Section V.

Two-thirds of surveyed countries reported that they undertake risk-assessments in processing VAT refund claims (see Appendix Table A5). The risk-assessment models vary, however, in scope and levels of sophistication. At one end of the spectrum are the highly developed risk-assessment processes and systems such as those used in the United Kingdom. These involve gathering information and intelligence from a wide range of sources and, through use of computer applications and statistical methods, identifying suspicious 
transactions (which may involve organized crime groups) for closer scrutiny. At the other end of the spectrum are more rudimentary and often subjective processes, performed without the support of computers or wide-ranging information, to categorize claimants according to risk-profiles.

Survey responses from a number of African and Latin American countries are contradictory in that the respondents report that they conduct risk-assessments, yet they also report that every VAT refund claim is subject to verification prior to payment.

\section{A quarter of survey respondents indicated a statutory requirement to verify every refund} claim prior to payment - see Appendix Table A5. Others reported that, while they do not have this feature in their VAT laws, their aim is to verify all claims as a matter of administrative practice. Not all verification activities are undertaken by the tax authorities. Tanzania reported that under its VAT laws, for example, every refund claim must be verified by an auditor registered by the Tanzanian national board of accountants and auditors.

A third of countries reported that they do not have a VAT audit program, and for those that do, pre-refund audits dominate the audit program in a quarter of the countries concerned. Reasons cited by many developing and transitional countries for failure to implement effective audit programs include: (1) insufficient numbers of highly skilled and appropriately remunerated audit practitioners; (2) the authorities' concerns about collusion between taxpayers and auditors; (3) inadequate preparation at the time of VAT implementation, possibly because the consequences of a weak audit program were not immediately perceptible; (4) the lack of clear political support for the tax administration; and (5) the lack of an appropriate legal and judicial environment.

Advanced tax administrations (i.e., those applying principles of self-assessment and administering domestic VAT along with income tax in a function-based organizational structure) give strong emphasis to risk-based audit programs aimed at broad coverage of taxpayer groups and compliance issues. Selective verification of VAT refunds is simply one of many components of a wide-ranging audit program (see discussion in Section IV).

\section{E. Cooperation Between Revenue Agencies}

Exchange of VAT and income tax information. Audit and enforcement programs and risk management systems rely on effective exchange of VAT and income tax (and other) information. Where direct and indirect taxes are administered together in a unified tax administration, exchange of VAT and income tax information normally happens automatically. ${ }^{18}$ In countries where the VAT and income tax are administered by different departments or agencies, however, exchange of information is often limited. In some countries (e.g., Egypt and Tanzania), the income tax law does not allow income tax-related information to be provided to the VAT administration.

\footnotetext{
${ }^{18}$ Currently, of around 140 countries that have adopted a VAT, 120 or so have integrated function-based revenue administrations covering both income tax and VAT—see The Modern VAT.
} 
Exchange of VAT and customs information. As shown in Appendix Table A5, all countries surveyed have some form of information exchange between tax and customs agencies for purposes of verifying data in VAT returns and refund claims. This is essential, given that it is not unusual for half of a country's gross VAT revenues to be collected at the border. In some countries, the flow of information may be restricted to case-by-case requests (e.g., Mozambique and Tanzania), whereas in others there is periodic transmission of routine data (e.g., monthly data on import and export transactions). Some economies permit on-line access to customs data bases by tax officials (e.g., Singapore). In five countries (Canada, Mexico, Peru, South Africa, and the United Kingdom), VAT and customs administration was, at the time of the survey, carried out by the same government entity, thereby facilitating a freer flow of customs information to VAT auditors and staff involved in refund processing (although the flow of information was still subject to requirements imposed by the tax and customs laws).

Exchange of information among countries. The EU provides a good example of successful exchange of information among countries. EU member states exchange information about VAT registered traders and the value of their intra-Community supplies of goods via the EU's VAT Information and Exchange System (VIES). ${ }^{19}$ The European Commission has also been working on proposals to improve and strengthen administrative cooperation between tax authorities. The U.K. authorities have, for example, developed bilateral agreements with eight member states (with another three in the pipeline) to allow information to be exchanged more rapidly to help identify VAT fraudsters.

\section{F. Budgeting for VAT Refunds}

Less than 40 percent of the countries surveyed make specific expenditure appropriation for VAT refunds in their annual budgets. Most respondents pay refunds out of consolidated VAT revenue collections_-see Appendix Table A4.

\section{G. Organization and Management of VAT Refund Operations}

Almost half (47 percent) of the survey countries have dedicated organizational units responsible for processing VAT refunds. For others, refunds are processed either as part of broader returns-processing operations (as in Sweden, Hungary, and the Slovak Republic), or audit operations (as in Cambodia). In a number of countries (e.g., the Netherlands, New Zealand, and the United Kingdom), refunds are processed in central automated processing centers. A broad observation from the survey, and from FAD's work in developing and transitional countries, is that countries unwilling to embrace self-assessment procedures are more inclined to establish dedicated VAT refund units- the principal aim of

\footnotetext{
19 The VIES allows exchange of information among EU member states about VAT-free intra-Community supplies of goods. The database was created in 1992 to help ensure that VAT is accounted for in the member state to which the goods are destined.
} 
which, in many cases, is to control transactions and verify all refund claims, preferably prior to payment.

\section{Administering VAT Refunds-Principles ANd Modern Practices}

A key feature of the invoice-credit form of VAT is that some businesses will pay more VAT on their purchases than they collect on the taxable sales they make, and so should be able to reclaim the difference from the tax authorities. As already noted, this is particularly true of exporters whose output is zero-rated. It is also true of businesses, particularly new ones, which have made large purchases relative to current sales. Refunds are part and parcel of the operation of the VAT - a tax that is designed to be borne by the final consumer, not by producers or suppliers. Any attempt by tax administrations to deny payment of legitimate refund claims alters the nature of VAT by making it, in part, a tax on production.

\section{A. Administering VAT in a Self-Assessment Environment}

Modern VAT systems, and their administration, operate on a principle of voluntary compliance, where taxpayers are expected to comply with their VAT obligations with limited intervention of revenue officials. Voluntary compliance is achieved through a system of selfassessment, where taxpayers, with access to information and assistance from the tax administration, calculate their own liabilities and refund entitlements, file returns, and pay tax and claim refunds that they themselves assess. If they fail to make accurate assessments and pay insufficient tax, or falsely claim refunds, they run the risk of being audited and subjected to penalties. Experience strongly suggests that VAT is feasible only as a selfassessed tax.

The tax administration's role in a self-assessment environment is to, first, assist taxpayers to understand their obligations and entitlements and, second, to take action against noncompliers-particularly those exhibiting the highest revenue risks. To do this, the tax administration must be organized appropriately, with adequate resources, and have in place compliance programs based on a balanced mix of education, assistance, enforcement, and verification. To the greatest extent possible, VAT systems should be supported by clear and simple laws and procedures that facilitate revenue administration and minimize taxpayer effort and compliance costs. Importantly, administrations should be provided with appropriate enforcement tools, including powers to conduct audits, reassess and collect liabilities, and impose penalties.

\section{B. Budgeting for VAT Refunds}

There are two methods of budgeting for VAT refunds: (1) making payments from gross VAT revenue (as 60 percent of the survey respondents do); or (2) paying from budget expenditure appropriations. The choice of which method to use is influenced by historical and legislative (constitutional) factors. Irrespective of the method employed, it is essential that tax authorities and finance ministries have suitable forecasting and monitoring systems in place to anticipate refund levels and make sufficient funds available to meet all legitimate refund claims when they occur. As indicated in Section III, a pattern of refund claims tends to 
develop within countries over time, meaning that authorities should be able to predict, with some degree of certainty, the level of refunds they might expect to pay throughout the year.

To ensure that tax authorities are not tempted to delay refunds during periods when collection targets are under pressure, suitable performance measures should be established to track actual collections and refunds against forecasts, with a requirement to explain variances.

\section{VAT Compliance Strategy}

Total elimination of losses from refund abuse and other VAT fraud and evasion is not realistic because of the costs involved - both for the tax administration and the business community. Tax administrations therefore need to strike a balance between applying effective controls to protect revenue, while ensuring that compliant taxpayers are not overburdened with compliance costs. This calls for a comprehensive VAT compliance strategy and program that applies risk-management principles, and encompasses critical taxpayer service and enforcement (audit, investigations, and sanctions) components.

A well-developed compliance improvement program identifies the major risks and how these will be addressed, together with criteria for evaluating progress in reducing the risks. The U.K. government has, for example, set its tax authority a target to stop the long-term growth in the size of the overall VAT gap (and to cut it from 15.8 percent in 2002-03 to 12 percent of the total amount that could be theoretically collected from VAT by 2005-06). To achieve this target, the tax authority has developed strategies aimed at the following:

$\checkmark$ Making it as easy as possible for legitimate traders to pay their VAT;

$\checkmark$ Making it as difficult as possible for dishonest traders to commit VAT fraud;

$\checkmark$ Challenging, through the courts, abusive VAT avoidance schemes;

$\checkmark \quad$ Detecting unregistered trading; and

$\checkmark$ Identifying traders who do not pay the correct amount of VAT.

\section{Detecting, Investigating, and Preventing Fraud}

FAD has already made a few studies on the topic of VAT fraud and evasion, and the methods to detect, investigate, and prevent it. ${ }^{20}$ More comprehensive studies are still needed, however, given the importance of the topic and the significant difficulties faced by many developing and transitional countries in implementing successful audit programs to address VAT fraud. As discussed in previous FAD publications, fraud and evasion come in many forms, ranging from traders omitting the occasional sale from their accounting records to systematic suppression of sales and falsification of invoices. Other fraudsters have little or no legitimate business activity and register for the sole purpose of stealing VAT through the refund system.

\footnotetext{
${ }^{20}$ See Value Added Tax, International Practice and Problems, Tait (IMF, 1988); and The Modern VAT.
} 
Box 2 summarizes the main types of fraud and evasion that, to varying levels, occur in all countries administering the VAT.

\section{Box 2. Types of VAT Fraud and Evasion}

Inflated refund claims. The simplest method is to create fake invoices for purchases never made. Indeed, organized crime networks have been known to establish businesses solely to fabricate invoices for sale to those wishing to defraud the revenue.

Underreported sales. This is the most usual way of evading VAT. Evasion by small operators is common, particularly in retail services where taxable inputs are small relative to taxable sales. By concealing sales to the domestic market, traders may not only evade their own obligation to charge VAT on their output, but, also, generate excess credits to be refunded.

Fictitious traders. This involves creation of short-lived sham enterprises that register for VAT and create the illusion of trading in goods and services. A common ploy is to invent fake export invoices on nonexistent goods and claim VAT refunds.

Domestic sales disguised as exports. Under this scheme, traders sell goods on the domestic market but claim a refund using a fake export invoice.

Missing trader intra-EU fraud. Typically, a fraudster registers for VAT in an EU country (e.g., the United Kingdom), purchases goods VAT-free from another EU member state, sells those goods at VAT-inclusive prices for home market consumption (in the United Kingdom), and then ceases operations after a period of intense trading and disappears without paying the VAT due.

A more common and lucrative variant is carousel fraud where, instead of being sold for consumption on the (U.K.) home market, goods are sold through a series of contrived transactions before being sold to a trader in another EU member state, who then sells the goods back to the United Kingdom. This allows the fraudsters to carry out the fraud repeatedly using the same goods.

Other forms of evasion and fraud include:

$\checkmark$ Traders that are liable to VAT but do not register;

$\checkmark \quad$ Credit claimed for taxable supplies used in exempt activities, and credit claimed on private purchases;

$\checkmark \quad$ Credit claimed for invoices from unregistered suppliers;

$\checkmark$ Goods imported illegally, and then sold with VAT added but not remitted to the tax authorities; and

$\checkmark$ Barter arrangements hidden from the authorities.

\section{Understanding the scale of VAT fraud and evasion is essential to effective compliance} management. In practice, however, estimating VAT losses from refund abuse can be very difficult. It requires specialist skills, soundly based statistical and economic assumptions, and an ability to interpret trends and draw sound conclusions where there is uncertainty in much of the underlying data. Some tax administrations engage economic consulting firms and academic institutions to assist in estimating VAT losses.

\section{Information gathering, intelligence work, and risk-assessment are critical in identifying business sectors and trader characteristics that present the greatest risks to the revenue.} Intelligence staff also help target organized crime groups involved in systemic VAT refund fraud. In the U.K. VAT administration, for example, the intelligence unit gathers and analyses information from a wide range of different sources, including customs, inland revenue, and other government agencies (e.g., the national criminal intelligence service). Similar approaches are also followed by other advanced tax administrations, where computer 
systems and statistical methods are used to compare information provided in VAT returns with other information, such as trends in industry sectors, to identify cases for further examination by field auditors.

Execution of a well-designed audit program is critical to reduce the incidence of VAT refund abuse. The most effective audit programs are those developed within an overall risk-management framework, and marked by the following design features and principles:

$\checkmark$ A broad coverage of taxpayer groups, by size and by sector, and of compliance issues;

$\checkmark$ Audit resources spread across all elements of the program, ensuring that a disproportionate share is not absorbed in verifying refund claims prior to payment (as appears to be the case in a number of the surveyed countries);

$\checkmark$ Pre-refund audits limited to high-risk cases only (typically to the first refund claim by a new VAT registrant, or to cases where claims vary significantly from established refund patterns and trends), while lower-risk claims are subjected to selective post-refund audits;

$\checkmark \quad$ VAT audits that are primarily short, issue-oriented (checking, for example, credits claimed for taxable supplies to exempt activities, or on private purchases), and limited to one or two tax periods;

$\checkmark$ Audits of accounting systems rather than individual transaction checking, especially with large taxpayers;

$\checkmark$ Close coordination of the VAT audit program with audit programs of other taxes, particularly income tax (in practice, this will include conducting comprehensive (or full) audits which cover all of a taxpayer's tax obligations over a number of tax periods);

$\checkmark$ Consistent application of appropriate penalties for noncompliance; and

$\checkmark$ Investigation of cases involving serious fraud with a view to prosecution under the criminal code.

Box 3 describes the range of audit types undertaken by modern tax administrations, highlighting the earlier important point that verification of refund claims is but one component of a much wider risk-based audit program aimed at broad coverage of taxpayers and compliance issues. 


\section{Box 3. Description of Audit Types}

In a function-based tax administration, the audit program typically includes the following range of audits.

Registration checks. These quick checks establish whether businesses are correctly registered for all tax obligations, including VAT. Information from third parties (e.g., customs and business licensing centers), as well as from other audit activities, may alert the tax administration that a registration check should be undertaken.

Advisory audits. These involve auditors visiting new enterprises to advise them of their obligations and entitlements, covering areas such as filing and payment, refund claims, record-keeping, risk of audit, and sanctions for noncompliance. These visits are particularly appropriate when introducing new tax laws.

Record-keeping audits. These take the form of unannounced visits to the taxpayer's business premises to check that appropriate records are being kept and that VAT invoices are being issued.

Desk audits. Audits generally require field visits; however, it may be possible to undertake some basic checks from the tax office. These checks may include examining VAT and income tax returns, undertaking selective cross-checking of information, and conducting ratio analysis. Desk audits generally apply to specific areas of enquiry, and to small business enterprises and individual (non-business) taxpayers, and may lead to further investigation.

Single- issue audits. These focus on a single tax type, or a specific (usually limited) tax period. For VAT, this type of audit would cover one or two returns only.

VAT refund audits. These involve verifying a taxpayer's entitlement to a refund prior to the refund being processed. They are usually undertaken in respect of a taxpayer's first refund claim, as well as in situations where a refund claim varies significantly from established patterns and trends. Some administrations have highly developed outbound telephone verification processes, whereby taxpayers and their suppliers are contacted to provide details about particular refund claims. Taxpayers/suppliers may be asked to provide copies of invoices to the tax authority for purposes of substantiating refund claims.

Audit projects. Audits may be managed on a project basis, covering a specific group of taxpayers. Audit projects may cover an industry (e.g., construction) or a line of business (e.g., retail), and/or certain items from the return. They involve specific checks designed to address a particular risk or determine the level of compliance in a particular sector.

Comprehensive (or full) audits. These audits cover all tax obligations over a number of tax periods and, typically, are undertaken following discovery of discrepancies during single issue audits. They are timeconsuming and comprehensive in nature, and should be applied only to taxpayers showing evidence of underreporting across income tax, VAT, and other taxes.

Fraud investigations. These involve the most serious cases of noncompliance that have criminal implications. They require special skills in investigation, including meeting evidentiary requirements, and often involve seizure of records, taking testimony from witnesses, and preparing briefs for courts.

\section{E. VAT Registration}

A tax authority's ability to administer the VAT effectively-including the processing of refund claims - is influenced by the level of the threshold for compulsory registration. Experience suggests that many countries have tended to set the threshold too low, finding themselves in difficulty when the capacity of their tax administration is found to be insufficient to manage the number of registered taxpayers. A recommendation frequently made by FAD, therefore, is to regulate the number of VAT taxpayers (by adjusting the VAT registration threshold) at a level that can be realistically managed by the tax administration. This means that, where administration is weak, a high VAT threshold should be maintained until such time as the tax authority's capacities are developed to enable it to administer a 
larger number of VAT taxpayers in a self-assessment environment (i.e., until such time as the tax authority is organized appropriately, has adequate resources and systems, and has established effective enforcement and service programs).

The VAT registration process should contain sufficient checks and controls to prevent registration of fictitious traders intent on stealing from the refund system. Applicants for registration should be required to provide proof of identity, along with basic information about intended trading activities (e.g., the nature and location of business operations; anticipated turnover; the type of goods or services to be traded/provided; sources of supply; and sources of business finance). Registration staff should then assess this information against risk criteria to identify potential fraudsters. A short interview with the applicant may be necessary, and automatic computer checks of internal and external databases may also be undertaken to validate information. For the vast majority of cases, this procedure would be sufficient to establish the authenticity of the applicant, and the registration could proceed without significant cost or delay for the taxpayer.

Where registration officers have doubts about the veracity of the claims, the case should be referred to enforcement staff for further checking, including a visit to the business premises to verify that business operations exist, and verification of sources of business finance. VAT registration should be refused where preregistration checks establish a strong risk of fraud. If preregistration checks raise suspicions, but there is insufficient evidence to refuse registration, the tax authority may require a financial security to be lodged by the applicant (including requiring the applicant to demonstrate the source of the financial security paid).

\section{F. Taxpayer Service}

In response to demands by the business community for improved services from tax administrations, there has been a growing trend to introduce fast-track refund processing for taxpayers with proven records of good compliance. Competition for global markets is making governments increasingly sensitive to business needs and costs associated with VAT systems. Exporters in particular are quick to complain about cash-flow impacts of delayed refunds. Approaches that give preferential treatment to good compliers are discussed in Section V. Tax administrations are also, increasingly, giving greater emphasis to helping traders understand their VAT obligations and entitlements, including requirements relating to refund claims. Priority is often given to assisting new businesses (often working in cooperation with industry bodies and other government agencies) and taxpayers operating in the shadow economy who may not be fully aware of the VAT registration requirements.

In giving close attention to new registrants, a tax administration may also identify and prevent potential fictitious traders from carrying out fraud through the VAT refund system. 


\section{SPECIFIC Approaches}

This section describes and evaluates specific approaches that have been adopted by several countries to deal with VAT refund problems, in part as a substitute for an effective VAT compliance strategy based on risk-management principles.

\section{A. Zero-Rating Supplies to Exporters}

When France adopted the first VAT-type tax with an invoice-based credit mechanism in 1948, a specific scheme (Le système des achats en franchises) was implemented to allow regular exporters to purchase their business inputs free of tax. The aim of the scheme, which in effect applied a zero-rate to supplies made to exporters, was to eliminate the need for exporters to claim refunds of excess credits. The scheme was further developed in 1954 and 1968, when the structure of the tax was improved to become a modern VAT (including broadening the base and extending the VAT credit mechanism). ${ }^{21}$

When the VAT was introduced in other European member states in the 1970s, some of them (e.g., Ireland, ${ }^{22}$ Italy, and the Netherlands) adopted the zero-rating scheme for their exporters, although the Netherlands later abandoned it in the 1990s. While the Sixth Directive provides EU member states with the option of adopting this system, only a limited number have done so. In the 1980s, the scheme was introduced in several former French colonies (including Algeria, Côte d'Ivoire, Morocco, Tunisia, and Senegal), and in the 1990s in a few transition and emerging market countries (e.g., Korea, Albania, and Azerbaijan). ${ }^{23}$

Although the scheme may have facilitated introduction of the VAT in France in the early $1950 s,{ }^{24}$ it has since been shown to add complexity and revenue risks to VAT administration, largely because the scheme breaks the VAT credit chain. Zero-rating supplies to exporters effectively shifts the problem of controlling refund claims away from a small number of well-known exporters to an often larger and lesser-known group of suppliers. The certificate mechanism, such as that operating in Azerbaijan, is open to abuse, and adds to administrative workloads in monitoring the activities of downstream suppliers.

\footnotetext{
${ }^{21}$ The current scheme is limited to direct exporters and operates under self-assessment principles. Exporters who qualify for the scheme advise their suppliers in writing not to charge VAT, except for capital goods. Zero-rated supplies to exporters are subject to an annual ceiling, equal to the total value of exports made by the exporter in the previous year. At year-end, each exporter subject to the scheme must provide the tax authorities with details of purchases and exports made during the year. New exporters must seek approval from the authorities to enter the scheme, and delinquent taxpayers can be removed from the scheme.

${ }^{22}$ In Ireland, traders who export more than 75 percent of their output can obtain an authorization that allows their suppliers not to charge VAT.

${ }^{23}$ In Azerbaijan, zero-rate authorization certificates are issued by the tax authorities to exporters in the hydrocarbon sector, as well as to their direct suppliers. The direct suppliers in turn provide copies of certificates to their suppliers, thus giving suppliers further down the chain authority not to charge VAT.

24 The modernization of the French tax administration-including integration of the direct and indirect tax administration (from 1948), the development of comprehensive audit programs (from 1954), and the establishment of full function-based tax offices (from 1968)_-is closely linked to implementation and improvement of its VAT system (see The Modern VAT).
} 


\section{B. Large-Scale Cross-Checking of Invoices}

Attracted by the theoretical possibility that a tax administration should be able to crosscheck all purchases and sales invoices to validate VAT credit claims (as well as identify undisclosed sales), a few countries have attempted computerized cross-checking of invoices on a grand scale. The first to do this was Korea, commencing an ambitious cross-checking program in the late 1970s. More recent attempts have been made by China and a handful of other countries (e.g., Indonesia, Bulgaria, Azerbaijan, and Albania). A feature of the systems developed by these countries is that they require taxpayers to submit copies (or a list) of invoices with their regular VAT returns, details of which are then entered into a central database. Box 4 briefly describes the experiences of Korea and China.

\section{Box 4. Large-Scale Cross-Checking of Invoices_Korea and China}

Korea. Korea commenced development of a computer-based invoice-matching system in the 1970s when electronic data capture was not readily available. The system required the tax administration to transcribe data from paper copies of invoices supplied by vendors and purchasers. Data capture was time-consuming, costly, and prone to error. Taxpayer compliance costs were also high, given that suppliers and purchasers were required to submit copies of invoices with their VAT returns.

The system identified numerous mismatches, and considerable administration resources were consumed in examining these. Most mismatches were not due to fraudulent claims, but instead were the result of transcription errors, incomplete data, and valid timing differences.

A form of large-scale invoice cross-checking continues to be undertaken in Korea today, requiring general VAT taxpayers to supply the tax authority with summary information of purchases and sales invoices (replacing the earlier requirement that traders submit copies of invoices).

China. China has developed a computerized cross-checking system-known as the "Golden Tax Program" (GTP) - to identify false invoices and verify credit entitlements, as well as check reported sales on VAT returns and assist audit case selection generally. The system does not operate in all provinces and is applied to mid-scale and large enterprises.

Under the system, a VAT taxpayer is given a smartcard and software-herein referred to as the "black box"which is activated when an invoice for a taxable supply is generated within the taxpayer's computerized accounting system. The "black box" generates an encrypted code_-an 84-digit number-which is printed on the VAT invoice (VAT invoice forms are accountable documents supplied by the authorities). Information contained in the encrypted code includes the registration numbers of the supplier and purchaser, the sales price, the nature of the goods, and VAT charged. This information is stored on an electronic file that, at the end of the tax period, is copied to a disk and submitted to the tax authorities for input to the GTP database. Invoice details supplied by purchasers (when they file their VAT returns) are subsequently cross-checked with the information held in the database.

While the authorities report that the GTP has had a positive impact on VAT compliance, no details in this regard have been obtained. Details of the costs involved in developing and administering the system, and taxpayer compliance costs, are also unknown.

Despite dramatic improvements in recent years in information technology, including automated data capture, the administrative and taxpayer compliance burden associated with large-scale invoice matching continues to be significant. Recent diagnostic reviews by FAD of invoice cross-checking systems have shown that these systems continue to generate considerable unproductive work. In one country, for example, FAD observed that more than half of the large taxpayer unit's highly skilled auditors were substantially engaged in 
following-up and checking invoice discrepancies reported from the invoice matching system. Examination of the discrepancies revealed that many related to data entry errors (e.g., errors in taxpayer identification numbers and addresses), thereby creating administrative costs with no associated revenue benefits.

FAD remains of the view that large-scale cross-checking systems are a poor substitute for well-designed audit programs based on risk assessments, selective cross-checking, intelligence gathering, and targeted fraud investigation. The net benefits of large-scale crosschecking systems are yet to be proven, with associated costs to businesses and tax administrations continuing to be unacceptably high. Cross-checking should be directed at industries and taxpayer groups exhibiting the highest potential for invoice-related fraud, and should be applied on a sample basis or where a tax auditor has grounds for suspicion.

\section{Certification of Refund Claims by CPAs}

Under Kenya's VAT laws, refund claims exceeding a specified amount must be certified by a CPA registered with the Institute of Certified Public Accountants of Kenya. The law imposes sanctions on accountants who knowingly certify false claims. Tax authorities, traders, and accounting professionals all contend that this approach has benefits. Tax officials argue that it helps eliminate fraudulent claims, and reduces administrative costs. Kenyan officials report that the number of refund claims by exporters dropped by 40 percent following introduction of the scheme, suggesting that many firms had been submitting false claims. By placing the onus on CPAs to certify the validity of refund claims, the government has in effect outsourced, in part, its verification program. Large exporters support the arrangement because it speeds up refunds, and for this they are willing to bear the increased compliance costs. CPA firms are also in favor because of the opportunity to generate service fees.

To ensure that an added financial burden is not placed on traders requesting small refunds, CPA certification is required for larger refund claims only. This is achieved by setting the statutory threshold at an appropriate level. For the scheme to work effectively, it requires a high-integrity (noncorrupt) accounting profession, together with a sufficiently strong tax administration and sound judicial system to enforce sanctions if required. It also requires acceptance by traders of additional compliance costs.

\section{Preferential Treatment of Good Compliers (“Gold” Status Scheme)}

A number of countries give preferential treatment to taxpayers (especially exporters) with sound compliance histories. One approach is the so-called "gold" status scheme, under which exporters with good compliance reputations obtain accelerated VAT refunds. "Silver" status taxpayers, and those in lower groups, receive less prompt treatment. Introduction of such approaches frees-up scarce audit resources for more productive audit work.

In countries with limited administrative capacity, this system can be introduced initially with manual procedures. For example, Pakistan introduced it, with some success, in the late 1990s to improve the processing of VAT refunds, especially for exporters in the textile sector. The system was further improved, and basic computer applications were developed to provide 
information on traders' compliance history, using information from the VAT, income tax, and customs administrations.

Under the scheme operating in Pakistan, refund claimants are categorized in three main groups: (1) "gold" for claimants exhibiting minimal revenue risk; (2) "silver" for moderate risk claimants; and (3) "others,” representing those of high or unknown risk. Table 5 outlines the type of criteria used in categorizing taxpayers. Gold refund claimants normally have their claims approved for payment, without a pre-refund audit, within 3-5 days. Silver claimants are assigned an upper refund limit, where claims not exceeding the limit are subject to a brief desk review and approval is given within 15 days. Post-refund audits are conducted at least once a year on two or three claims submitted in the past 12 months by gold and silver claimants. If the post-refund audits detect persistent inaccurate claims, the gold or silver status of a claimant is withdrawn.

Refund claims from taxpayers without gold or silver status are processed (paid or denied) within the statutory deadline. Claims are selected for pre-refund verification in the following circumstances:

$\checkmark$ The claim is a first-time refund claim.

$\checkmark$ The claim exceeds a value prescribed by the tax administration.

$\checkmark$ The claim deviates from the regular refund pattern of the claimant.

$\checkmark$ Previous claims have been rejected or reduced as a result of verification checks.

$\checkmark$ The claimant has a record of poor compliance in relation to VAT and other taxes (e.g., nonfiling, and late payment).

Table 5. Pakistan: Requirements to Qualify as a “Gold” and “Silver” Taxpayer

\begin{tabular}{|c|c|}
\hline Gold & Silver \\
\hline $\begin{array}{l}\text { Exporters with at least three years’ export history } \\
\text { and net wealth exceeding a specified amount }\end{array}$ & $\begin{array}{l}\text { Exporters with at least one year export history and net } \\
\text { wealth exceeding a specified amount }\end{array}$ \\
\hline $\begin{array}{l}\text { Proper books of account for at least the last } \\
\text { three years }\end{array}$ & $\begin{array}{l}\text { Proper books of account for the duration of taxable } \\
\text { activities (or three years, whichever is the lesser) }\end{array}$ \\
\hline $\begin{array}{l}\text { No evidence of fraud or significantly overstated } \\
\text { refund claims in the past three years }\end{array}$ & Consistent pattern of export activities and products \\
\hline $\begin{array}{l}\text { History of accurate and timely tax remittance for all } \\
\text { taxes and duties }\end{array}$ & $\begin{array}{l}\text { History of accurate and timely tax remittance for at } \\
\text { least the past } 12 \text { months }\end{array}$ \\
\hline Bank certification that accounts are in good standing & $\begin{array}{l}\text { No evidence of fraud or overstated credit claims in at } \\
\text { least the past four refund claims }\end{array}$ \\
\hline $\begin{array}{l}\text { Records audited by the tax office for six of the past } \\
24 \text { months }\end{array}$ & $\begin{array}{l}\text { Records audited by the tax office for three of the past } \\
24 \text { months }\end{array}$ \\
\hline
\end{tabular}


The refund program for gold, silver, and other claimants depends heavily on developing profiles for each claimant. In addition to a complete record of VAT compliance, these profiles include the taxpayer's compliance history and audit results for all other taxes.

\section{E. Payment for Large Purchases Through the Banking System}

The widespread use of cash transactions in developing and transitional economies facilitates VAT and other tax evasion, simply because an audit trail may not be established for the tax authorities to follow in identifying and verifying sales and purchases. To tackle this problem, tax administrations have looked for ways of encouraging, and even forcing, traders to conduct their business through the banking system-particularly where larger amounts are involved. One approach has been to introduce so-called VAT bank accounts, which are discussed below. Two other approaches are discussed here.

The first involves a measure introduced in many countries (including France, Hungary, Turkey, and several other countries) requiring traders to pay for goods and services above a certain transaction threshold amount through the banking system. Failure to comply results in a financial penalty. The second approach, adopted in Azerbaijan, introduces a stronger incentive for businesses to move away from cash transactions. For a VAT-registered enterprise in Azerbaijan to be entitled to VAT credits on a business-related purchase, the purchase must be made through the banking system. If the purchase is made in cash, VAT credits are denied.

Such measures can be expected to reduce the incidence of unreported transactions by registered traders. However, they have sometimes been less effective than anticipated. For example, Turkey's experience is that the measure has not met expectations because detection of noncompliance has been difficult, and the basis on which the scheme was introduced-by way of ministerial direction-has been challenged in the courts. These measures are also unlikely to have an impact on the activities of unregistered traders who are unknown to the authorities. In the absence of programs specifically designed to identify and bring unregistered traders into the VAT net, these traders are likely to continue to operate undetected in the shadow economy. ${ }^{25}$

In the final analysis, none of the measures outlined should in any way be seen as a substitute for an effective system of VAT invoices and record-keeping requirements. Tax invoices and books of account provide the basis for taxpayers to prepare VAT returns and claim credits, and provide the source information for the authorities to conduct audits. Failure to comply with record-keeping obligations should attract appropriate penalties.

\footnotetext{
${ }^{25}$ Forcing traders to pass transactions through banks may, in some circumstances, be disruptive to business. Registered traders may, for example, prefer to be paid in cash where they are concerned about the solvency of customers, or because they have little faith that the banking system will transfer funds in a timely manner.
} 


\section{F. VAT Bank Accounts}

A VAT bank account system was introduced in Bulgaria in July 2002, with objectives of reducing VAT fraud and speeding up processing of VAT refund requests. Under the scheme, each taxpayer registered for VAT must open at least one VAT bank account. ${ }^{26}$ Further, a purchaser registered as a VAT taxpayer must deposit VAT payments into a seller's VAT bank account if the VAT charged on the transaction exceeds a statutorily prescribed threshold. The VAT deposit must be completed at the time the payment for the good or service is made. ${ }^{27}$ VAT input credits will not be denied to a purchaser who has followed the procedures and paid VAT into a seller's VAT bank account.

Figure 1 provides an example of how the VAT bank account system works. In the example, Firm A sells goods to Firm B, who then sells the goods to Firm C. In paying for the goods supplied by A, B must make two payments-one for the VAT exclusive price of the goods, and the other for the VAT that is payable on the goods. Payment of the VAT by B must be deposited into A's VAT bank account. ${ }^{28}$ The procedure is the same for Firm $\mathrm{C}$ in paying for goods supplied by $\mathrm{B}$. At the close of the VAT period, B and C can use monies held in their VAT bank accounts to meet their VAT liabilities due and payable to the government. Because B can demonstrate that the VAT due to A has been deposited into A's VAT bank account, B can be confident that VAT credits will be allowed for the amount paid. Likewise, $\mathrm{C}$ can be confident that credits will be allowed for VAT credited to B's VAT bank account.

As a general rule, funds held in VAT bank accounts can be used for two purposes only-for payment to suppliers of the VAT included in the price of the goods or services, and for payment of net VAT liabilities due and payable at the end of the tax period. In very limited circumstances, monies can be retrieved from VAT bank accounts for other purposes, but only on condition that a taxpayer (1) seeks the permission of the authorities to make the withdrawal; (2) undergoes a tax audit; and (3) transfers the required funds from the VAT bank account to the government bank account pending the audit outcome and clearance of the funds. If the audit determines that other tax liabilities are due and payable, the funds will not be returned to the taxpayer, and will be offset against those assessed liabilities. For the vast majority of taxpayers this means, in practice, that funds held in VAT bank accounts are effectively frozen and are lost as working capital of a business. Very few Bulgarian VAT taxpayers have applied to the authorities to withdraw funds from their VAT bank accounts.

\footnotetext{
${ }^{26}$ Bulgaria’s 80,000 or so VAT-registered businesses must open accounts in banks approved by the tax authority. The tax authority maintains a list of VAT bank account numbers, by VAT taxpayer name, and the list is publicly available (e.g., on an official website).

${ }^{27}$ Deposit information includes the VAT amount; the taxpayer identification numbers of the purchaser and seller; and the VAT invoice number relating to the transaction.

${ }^{28}$ A deposit to a seller's VAT bank account can be made via transfer from the purchaser's VAT bank account, if the balance is sufficient, or by direct payment. In this example, it is assumed that there are sufficient funds in B's VAT bank account to settle the VAT payment that is due to A.
} 
Figure 1. VAT Bank Account System

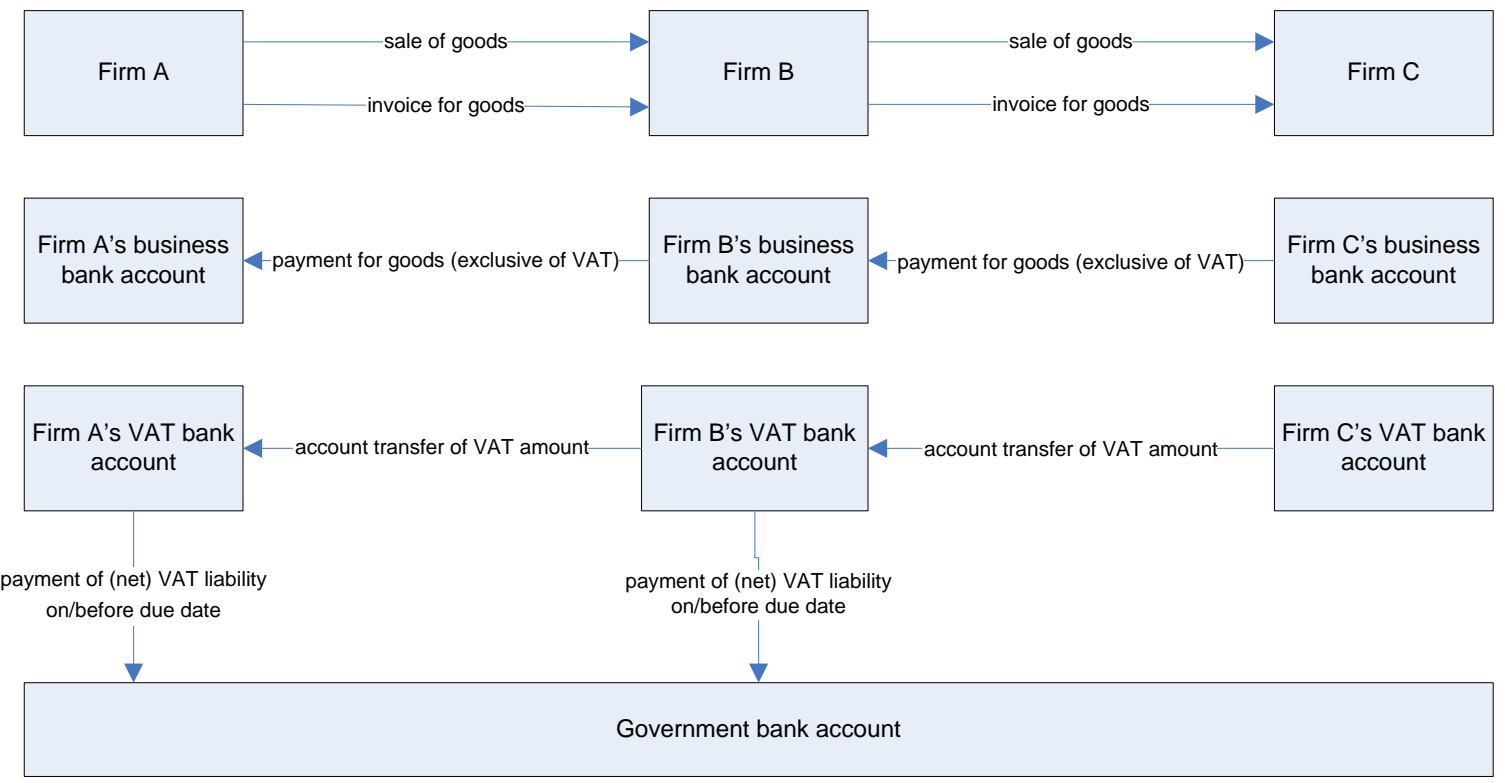

A full assessment of Bulgaria's VAT bank account system has not been possible because hard data have not been available to assess its impact on VAT revenue and refund delays. Some general observations can be made, however, particularly in relation to its potential impact on VAT fraud, and its underlying compliance costs.

The first observation is that the scheme does not provide a panacea against VAT fraud. There are many types of VAT fraud that will not be detected by the use of VAT bank accounts. For example, the VAT bank account system will not, of itself, detect underreporting of sales, false exporting, transactions occurring outside the VAT account system, bribing of tax officials, and false invoicing. Additionally, a deposit by a purchaser into a seller's VAT bank account is no guarantee that the tax will be deposited into the government's account.

The second observation is that the compliance costs imposed by the VAT bank account regime are considerable, including:

$\checkmark$ Loss of working capital—business enterprises have identified this as the most significant cost. Because funds held in VAT bank accounts are frozen, businesses could, potentially, be forced to seek short-term loan funds to support their cash flow needs.

$\checkmark$ Administration costs - under the VAT bank account system, businesses incur additional costs in having to make two payments (instead of one) for a good or service. The number of VAT invoices, payment orders, and bank account deposits and withdrawals is doubled. Because mutual offsets between sellers and purchasers are not allowed under the system, extra transactions result. Additional account-keeping fees also accrue.

A point to note in relation to the compliance burden occasioned by the VAT bank account system is that the costs are disproportionately higher for small to medium-sized businesses. 
A few transitional countries - including Russia-have considered adopting the VAT bank account system but, on closer examination of its compliance costs, have decided against it.

\section{G. Deferring Accounting for VAT on Imported Capital Goods}

Investors importing large items of capital equipment often complain that the levying of VAT on their imports has a negative effect on their cash flow and thereby discourages investment (i.e., the investors are required to pay VAT before clearance of their goods, and then have to wait for the resulting excess credit to be refunded following filing of their next VAT return). ${ }^{29}$ One solution to this problem is for countries to grant VAT exemptions to the investors, thereby dispensing with the need for refunds altogether. Governments are, however, generally reluctant to do this because of the potential for abuse, and the pressure it creates to extend VAT exemptions to other imports. A viable alternative, supported by FAD in developing countries, has been to permit VAT taxpayers to defer accounting for the VAT liability on the imported capital goods until filing of the next return. In this way, importers can offset the VAT liability with the input tax credit to which they are entitled. Box 5 describes how the scheme works.

\section{Box 5. Deferral Scheme for VAT Owing on Imported Capital Goods}

The main characteristics of the scheme are as follows:

$\checkmark \quad$ The scheme is limited to registered VAT taxpayers who import large items of capital goods.

$\checkmark$ Capital goods (both imported and domestic) are subject to the standard rate of VAT.

$\checkmark$ Imports of capital goods by persons who are not registered VAT taxpayers are subject to VAT at the time of import. VAT is paid, as usual, before clearance of the goods.

$\checkmark \quad$ Importers of capital goods who are registered VAT taxpayers are permitted to defer accounting for the VAT liability until their next return is filed.

$\checkmark \quad$ In this return, the VAT applicable to those goods is reported as a VAT liability and, in the same return, the VAT input tax credit is claimed for the capital goods.

$\checkmark \quad$ If the importer is entitled to 100 percent input tax credit (equipment used exclusively in taxable activities) the VAT applicable to the importation, reported as a liability, will be completely offset by the corresponding input tax credit.

$\checkmark$ The customs office is furnished with a copy of the VAT return to close their records of the importation.

\section{H. Evaluation of Specific Approaches}

The specific approaches outlined aim to satisfy one or more of the following objectives:

$\checkmark$ To reduce the number of refund claims;

$\checkmark$ To speed up refund processing;

\footnotetext{
${ }^{29}$ In some countries, start-up companies are further disadvantaged because they cannot register for VAT until they generate sales.
} 
$\checkmark$ To address trader cash flow concerns, and reduce other costs of compliance;

$\checkmark$ To shield the refund system from abuse, and enhance the VAT revenue base generally; and

$\checkmark$ To reduce costs of tax administration.

Table 6 provides a summary evaluation of each scheme against these objectives. Most schemes add to both administration costs and taxpayer compliance costs. Only scheme D (preferential treatment of good compliers) achieves a reduction in these costs, while at the same time accelerating refund payments for most traders and enhancing protection of the VAT revenue base. One drawback of the scheme, however, is that it tends to favor older established firms over new enterprises (but the effects of this can be cushioned if the tax administration complements the scheme with effective education and assistance programs for new enterprises). Two schemes in particular (VAT bank accounts and large-scale invoice matching) are yet to prove benefits that justify the considerable additional costs they impose.

Similarly, scheme A (zero-rating supplies to exporters) raises questions about whether real net benefits are delivered, given the complexity it adds to the VAT system. Scheme $C$ (certification of refund claims by CPAs) is worthy of consideration if traders are willing to accept additional costs, and if the accounting profession can be trusted to fulfill its role. It should not, however, be introduced as a means of compensating failures of a weak tax administration to develop its enforcement and other capacities to manage compliance properly. Schemes E (purchases paid through the banking system) and G (deferment of VAT on imported capital goods) may have a place in developing and transition economies, but should not be seen as longer-term solutions.

Table 6. Summary Evaluation of Specific Approaches Against Performance Criteria

\begin{tabular}{lccccc}
\hline & \multicolumn{5}{c}{ Performance Criteria } \\
\cline { 2 - 6 } & $\begin{array}{c}\text { Reduces or } \\
\text { eliminates } \\
\text { refund delay }\end{array}$ & $\begin{array}{c}\text { Reduces } \\
\text { number of } \\
\text { refund } \\
\text { claims }\end{array}$ & $\begin{array}{c}\text { Enhances } \\
\text { protection of } \\
\text { VAT } \\
\text { revenue base }\end{array}$ & $\begin{array}{c}\text { Reduces } \\
\text { taxpayer } \\
\text { compliance } \\
\text { costs }\end{array}$ & $\begin{array}{c}\text { Saves } \\
\text { admin } \\
\text { resources }\end{array}$ \\
\hline A. Zero-rated supplies to exporters & Yes & Yes & No & No & No \\
B. Large-scale cross-checking of invoices & No & No & Yes & No & No \\
C. Certification of refund claims by CPAs & Yes & No & Yes & No & Yes \\
D. Preferential treatment of good compliers & Yes & No & Yes & Yes & Yes \\
E. Purchases paid through banking system & Yes & No & Yes & No & No \\
F. VAT bank accounts & No & No & Not proven & No & No \\
G. Deferment of VAT on capital goods & Yes & Yes & No & No & No \\
\hline
\end{tabular}




\section{Suggested Model of Best Practice}

Successful tax administrations have found that the most efficient and effective VAT refund processing systems are those that (1) distinguish between refund claimants with a history of compliance and those claimants with poor or unknown compliance histories (this entails maintaining historical profiles for each refund claimant); (2) use pre-refund audits for high-risk refund claims and post-refund audits for claims of lesser perceived risk; and (3) apply criteria to determine the likely extent of revenue risk associated with each refund claim.

Against this background, some desirable features of an effective VAT refund system - that are particularly suitable for developing and transitional countries-are outlined below.

$\checkmark$ The number of VAT payers should be kept at a level that can be realistically managed by the tax administration. A high VAT registration threshold should be maintained until the tax authority is sufficiently developed to administer a larger number of VAT payers and refund claimants in a self-assessment environment.

$\checkmark \quad$ VAT registration applications should be subject to proof of identity and other basic checks designed to prevent fictitious traders from entering the VAT system and stealing from the government through the refund system.

$\checkmark$ Suitable forecasting and monitoring systems should be established to anticipate refund levels and make sufficient funds available to meet all legitimate refund claims when they occur. Given that a pattern of refund claims tends to develop within countries over time, authorities should be able to predict, with some degree of certainty, the level of refunds they might reasonably expect to pay throughout the year.

$\checkmark$ Refunds should be processed (i.e., paid, offset, or denied) within a reasonable statutory period (e.g., 30 days of the date on which a refund claim is made). The statutory deadline may be extended in special circumstances, where (1) a filed VAT return is incomplete; (2) the taxpayer has outstanding tax returns; (3) the taxpayer has failed to respond within a reasonable period to verification enquiries; or (4) the tax authority suspects, on reasonable grounds, that the VAT return is inaccurate and/or the taxpayer is engaged in fraudulent activity, in which case the taxpayer should be subjected to audit and/or investigations. The tax administration should report publicly on its performance in meeting the statutory deadline for processing refunds.

$\checkmark \quad$ Interest should be paid on late refunds to compensate taxpayers with legitimate refund claims for being deprived of their working capital.

$\checkmark$ Excess VAT credits should be offset against VAT and other tax arrears, except where an outstanding amount is subject to a genuine dispute. To support this, the necessary taxpayer accounting and debt management systems need to be in place.

$\checkmark \quad$ Immediate refunds of excess VAT credits should always be paid promptly to exporters or to enterprises that export a large share of their products (e.g., where at least 50 percent of the turnover is attributed to export sales). As appropriate, other taxpayers may be 
required to carry-forward their excess credits for six months. If at the end of this period an amount of excess credit remains, that amount should be refunded to the taxpayer. ${ }^{30}$

$\checkmark$ Verification of VAT refund claims should be a component of a wider audit program aimed at achieving broad coverage of taxpayers and compliance issues. Pre-refund audits should be limited to high-risk cases only (e.g., the first refund claim by a new registrant), while lower-risk claims should be subjected to selective post-refund audits.

$\checkmark$ Preferential treatment should be given to regular exporters with sound compliance histories. Some tax administrations assign an approved refund level within their computer systems for taxpayers with sound compliance records and accounting practices. Others categorize refund claimants according to their compliance history and perceived level of risk. Low risk claimants receive automatic refunds, often within a few days of filing their claims. Selected higher risk taxpayers are required to substantiate their claims.

$\checkmark$ Appropriate sanctions should be consistently applied to taxpayers who falsely claim refunds, or do not comply with record-keeping requirements. Refund-related fraud should be prosecuted through the criminal justice system.

$\checkmark$ Taxpayers should be entitled to appeal, on reasonable grounds, a decision by the tax administration to withhold a refund. Such appeals should be considered by an independent tribunal and dealt with promptly.

$\checkmark$ The tax administration should provide clear information to taxpayers explaining their rights and obligations, and the procedures for making a refund claim. VAT returns and refund claim forms should be simple, have clear instructions, and be filed through means convenient to taxpayers.

\section{CONCLUSIONS}

In addressing problems associated with VAT refund processing, there is sometimes a tendency for tax administrations to deviate from the primary goal of building sound VAT systems based on improved voluntary compliance through effective systems of selfassessment. In reacting to attacks on the refund system, it can be easy to lose sight of longerterm objectives and introduce measures incompatible with self-assessment concepts, including measures that are intrusive and costly to all taxpayers irrespective of their compliance behavior. Experience strongly suggests that the VAT is feasible only as a selfassessed tax, meaning that substitutes for effective risk-based approaches within a selfassessment environment cannot be expected to provide sustainable solutions to compliance problems related to VAT refunds.

\footnotetext{
30 This feature is optional, since more advanced tax administrations — and the business community also—may not consider the carrying-forward of excess credits to be best practice.
} 
Table A1. List of Countries that Responded to the IMF Survey

\begin{tabular}{ll}
\hline 1 & Algeria \\
2 & Azerbaijan \\
3 & Bolivia \\
4 & Bulgaria \\
5 & Cambodia \\
6 & Cameroon \\
7 & Canada \\
8 & Chile \\
9 & Colombia \\
10 & El Salvador \\
11 & France \\
12 & Hungary \\
13 & Indonesia \\
14 & Ireland \\
15 & Italy \\
16 & Kazakhstan \\
17 & Kenya \\
18 & Latvia \\
19 & Mexico \\
20 & Mongolia \\
21 & Morocco \\
22 & Mozambique \\
23 & Netherlands \\
24 & New Zealand \\
25 & Pakistan \\
26 & Peru \\
27 & Poland \\
28 & Romania \\
29 & Russia \\
30 & Singapore \\
31 & Slovak Republic \\
33 & South Africa \\
36 & Sweden \\
\hline & Tanzania \\
34 & Ukraine \\
3 inited Kingdom \\
\hline
\end{tabular}


Table A2. Value of Refunds Paid in Percent of Gross VAT Collections, 1998-2001

\begin{tabular}{|c|c|c|c|c|}
\hline & 1998 & 1999 & 2000 & 2001 \\
\hline \multicolumn{5}{|l|}{ Africa } \\
\hline Cameroon & $\ldots$ & 7.3 & 7.8 & 11.3 \\
\hline Kenya & 6.8 & 6.5 & 7.4 & 8.0 \\
\hline Mozambique & $\ldots$ & 0.0 & 2.6 & 5.5 \\
\hline South Africa & 39.7 & 39.3 & 38.6 & 40.2 \\
\hline Tanzania & 2.2 & 5.6 & 6.1 & 6.8 \\
\hline \multicolumn{5}{|l|}{ Asia } \\
\hline Cambodia & 0.0 & 4.5 & 3.8 & 2.2 \\
\hline Indonesia & 10.9 & 12.6 & 12.8 & 13.1 \\
\hline Mongolia & 2.2 & 7.6 & 4.8 & 11.9 \\
\hline Singapore & 56.0 & 50.8 & 56.2 & 54.1 \\
\hline \multicolumn{5}{|l|}{ Europe } \\
\hline Bulgaria & 20.3 & 21.0 & 20.1 & 24.7 \\
\hline Hungary & 50.0 & 48.5 & 47.0 & 47.2 \\
\hline Poland & 33.3 & 32.8 & 38.2 & 38.3 \\
\hline Romania & 24.3 & 27.5 & 24.9 & 22.1 \\
\hline Slovak Republic & 56.6 & 53.1 & 50.3 & 55.6 \\
\hline France & 20.5 & 20.2 & 21.4 & 22.9 \\
\hline Ireland & 24.4 & 25.7 & 24.7 & 25.0 \\
\hline Italy & $\ldots$ & $\ldots$ & $\ldots$ & $\ldots$ \\
\hline Sweden & 48.5 & 47.1 & 50.2 & $\ldots$ \\
\hline Netherlands & $\ldots$ & $\ldots$ & 50.0 & 50.0 \\
\hline United Kingdom & 40.7 & 39.9 & 42.1 & $\ldots$ \\
\hline \multicolumn{5}{|c|}{ Former Soviet Union } \\
\hline Azerbaijan & $\ldots$ & $\ldots$ & $\ldots$ & $\ldots$ \\
\hline Kazakhstan & 16.9 & 10.9 & 23.1 & 17.3 \\
\hline Latvia & $\ldots$ & $\ldots$ & $\ldots$ & 49.1 \\
\hline Russia & 47.1 & 43.9 & 40.6 & 47.0 \\
\hline Ukraine & 16.6 & 15.8 & 27.0 & 37.1 \\
\hline \multicolumn{5}{|l|}{ Latin America } \\
\hline Bolivia & 9.0 & 10.2 & 11.3 & 10.9 \\
\hline Chile & 28.9 & 28.3 & 28.3 & 29.6 \\
\hline Colombia & 3.5 & 3.7 & 3.9 & 5.1 \\
\hline El Salvador & 11.5 & 9.6 & 10.2 & 6.9 \\
\hline Мexico & 33.4 & 34.1 & 30.6 & 30.1 \\
\hline Peru & 15.9 & 18.4 & 22.1 & 22.8 \\
\hline \multicolumn{5}{|l|}{ Middle East } \\
\hline Algeria & $\ldots$ & $\ldots$ & $\ldots$ & $\ldots$ \\
\hline Morocco & 3.5 & 6.3 & 6.1 & 4.7 \\
\hline Pakistan & 24.5 & 18.0 & 14.9 & 19.8 \\
\hline \multicolumn{5}{|l|}{ Other } \\
\hline Canada & 50.0 & 50.0 & 50.0 & 51.3 \\
\hline New Zealand & 32.5 & 34.4 & 37.4 & 37.8 \\
\hline
\end{tabular}

Source: IMF survey responses, IMF staff estimates, and World Economic Outlook. 
Table A3. Survey Responses I—All Countries

\begin{tabular}{|c|c|c|c|}
\hline & $\begin{array}{c}\text { Is There a Statutory } \\
\text { Deadline for Payment of } \\
\text { VAT Refunds? }^{1}\end{array}$ & $\begin{array}{l}\text { Are Taxpayers Entitled to } \\
\text { Interest on Refunds Paid } \\
\text { Late? }\end{array}$ & $\begin{array}{c}\text { Is There a Mandatory } \\
\text { Carry-Forward Period for } \\
\text { VAT Credits? }\end{array}$ \\
\hline \multicolumn{4}{|l|}{ Africa } \\
\hline Cameroon & Yes & No & No \\
\hline Kenya & No & No & Yes \\
\hline Mozambique & Yes & Yes & No \\
\hline South Africa & Yes & Yes & No \\
\hline Tanzania & Yes & Yes & Yes \\
\hline \multicolumn{4}{|l|}{ Asia } \\
\hline Cambodia & Yes & No & No \\
\hline Indonesia & Yes & Yes & Yes \\
\hline Mongolia & Yes & Yes & No \\
\hline Singapore & Yes & Yes & No \\
\hline \multicolumn{4}{|l|}{ Europe } \\
\hline Bulgaria & Yes & Yes & Yes \\
\hline Hungary & Yes & Yes & Yes \\
\hline Poland & Yes & Yes & Yes \\
\hline Romania & Yes & No & $\ldots$ \\
\hline Slovak Republic & Yes & No & Yes \\
\hline France & Yes & Yes & Yes \\
\hline Ireland & No & No & No \\
\hline Italy & Yes & Yes & Yes \\
\hline Sweden & Yes & Yes & No \\
\hline Netherlands & Yes & Yes & No \\
\hline United Kingdom & Yes & Yes & No \\
\hline \multicolumn{4}{|c|}{ Former Soviet Union } \\
\hline Azerbaijan & Yes & Yes & Yes \\
\hline Kazakhstan & Yes & Yes & No \\
\hline Latvia & Yes & No & Yes \\
\hline Russia & Yes & Yes & Yes \\
\hline Ukraine & Yes & Yes & $\ldots$ \\
\hline \multicolumn{4}{|l|}{ Latin America } \\
\hline Bolivia & Yes & No & Yes \\
\hline Chile & Yes & No & Yes \\
\hline Colombia & Yes & Yes & Yes \\
\hline El Salvador & Yes & No & Yes \\
\hline Mexico & Yes & Yes & Yes \\
\hline Peru & Yes & No & Yes \\
\hline \multicolumn{4}{|l|}{ Middle East } \\
\hline Algeria & No & No & Yes \\
\hline Morocco & Yes & No & Yes \\
\hline Pakistan & Yes & Yes & Yes \\
\hline \multicolumn{4}{|l|}{ Other } \\
\hline Canada & Yes & Yes & No \\
\hline New Zealand & Yes & Yes & No \\
\hline
\end{tabular}


Table A4. Survey Responses II-All Countries

\begin{tabular}{|c|c|c|c|}
\hline & $\begin{array}{c}\text { Can VAT Refunds be } \\
\text { Offset Against Other Tax } \\
\text { Liabilities? }\end{array}$ & $\begin{array}{c}\text { Are Refund Claims } \\
\text { Subject to a Minimum } \\
\text { Excess Credit Threshold? }\end{array}$ & $\begin{array}{c}\text { Are VAT Refunds Paid } \\
\text { From Consolidated VAT } \\
\text { Revenues or From a } \\
\text { Budget Expenditure } \\
\text { Item? } \\
\end{array}$ \\
\hline \multicolumn{4}{|l|}{ Africa } \\
\hline Cameroon & Yes & Yes & Revenue \\
\hline Kenya & Yes & Yes & Revenue \\
\hline Mozambique & Yes & Yes & Revenue \\
\hline South Africa & Yes & Yes & Revenue \\
\hline Tanzania & Yes & No & Revenue \\
\hline \multicolumn{4}{|l|}{ Asia } \\
\hline Cambodia & Yes & No & Expenditure \\
\hline Indonesia & Yes & No & Revenue \\
\hline Mongolia & Yes & No & Expenditure \\
\hline Singapore & Yes & Yes & Revenue \\
\hline \multicolumn{4}{|l|}{ Europe } \\
\hline Bulgaria & Yes & No & Revenue \\
\hline Hungary & Yes & No & Revenue \\
\hline Poland & Yes & Yes & Revenue \\
\hline Romania & Yes & No & Revenue \\
\hline Slovak Republic & Yes & No & Revenue \\
\hline France & No (except large taxpayers) & Yes & Expenditure \\
\hline Ireland & Yes & No & Revenue \\
\hline Italy & Yes & Yes & Expenditure \\
\hline Sweden & Yes & No & Revenue \\
\hline Netherlands & Yes & No & Revenue \\
\hline United Kingdom & No & No & Revenue \\
\hline \multicolumn{4}{|l|}{ Former Soviet Union } \\
\hline Azerbaijan & Yes & No & $\ldots$ \\
\hline Kazakhstan & Yes & No & Revenue \\
\hline Latvia & Yes & No & Revenue \\
\hline Russia & Yes & No & Expenditure \\
\hline Ukraine & Yes & $\ldots$ & Expenditure \\
\hline \multicolumn{4}{|l|}{ Latin America } \\
\hline Bolivia & No & No & Expenditure \\
\hline Chile & Yes & No & Revenue \\
\hline Colombia & Yes & No & Expenditure \\
\hline El Salvador & Yes & No & Expenditure \\
\hline Mexico & Yes & No & Revenue \\
\hline Peru & Yes & Yes & Expenditure \\
\hline \multicolumn{4}{|l|}{ Middle East } \\
\hline Algeria & No & No & Expenditure \\
\hline Morocco & No & No & Revenue \\
\hline Pakistan & Yes & No & Revenue \\
\hline \multicolumn{4}{|l|}{ Other } \\
\hline Canada & Yes & No & Revenue \\
\hline New Zealand & Yes & No & Revenue \\
\hline
\end{tabular}

Source: IMF survey. 
Table A5. Survey Responses III—All Countries

\begin{tabular}{|c|c|c|c|}
\hline & $\begin{array}{c}\text { Are Risk-Assessment } \\
\text { Approaches Applied in } \\
\text { Processing VAT Refund } \\
\text { Claims? }\end{array}$ & $\begin{array}{l}\text { Does the Law Require } \\
\text { Verification of Every } \\
\text { Claim Prior to Payment? }\end{array}$ & $\begin{array}{c}\text { Is Information } \\
\text { Exchanged Between Tax } \\
\text { and Customs } \\
\text { Administrations for } \\
\text { Purposes of VAT } \\
\text { Administration? } \\
\end{array}$ \\
\hline \multicolumn{4}{|l|}{ Africa } \\
\hline Cameroon & Yes & Yes & Yes \\
\hline Kenya & Yes & No & Yes \\
\hline Mozambique & Yes & Yes & Yes \\
\hline South Africa & Yes & No & Yes $^{1}$ \\
\hline Tanzania & Yes & Yes & Yes \\
\hline \multicolumn{4}{|l|}{ Asia } \\
\hline Cambodia & No & No & Yes \\
\hline Indonesia & Yes & Yes & Yes \\
\hline Mongolia & No & Yes & Yes \\
\hline Singapore & Yes & No & Yes \\
\hline \multicolumn{4}{|l|}{ Europe } \\
\hline Bulgaria & Yes & No & Yes \\
\hline Hungary & Yes & No & Yes \\
\hline Poland & Yes & Yes & Yes \\
\hline Romania & $\ldots$ & Yes & $\ldots$ \\
\hline Slovak Republic & Yes & No & Yes \\
\hline France & Yes & No & Yes \\
\hline Ireland & Yes & No & $\ldots$ \\
\hline Italy & Yes & No & Yes \\
\hline Sweden & Yes & No & Yes \\
\hline Netherlands & Yes & No & Yes \\
\hline United Kingdom & Yes & No & Yes $^{1}$ \\
\hline \multicolumn{4}{|c|}{ Former Soviet Union } \\
\hline Azerbaijan & No & No & Yes \\
\hline Kazakhstan & No & Yes & Yes \\
\hline Latvia & Yes & No & Yes \\
\hline Russia & $\ldots$ & Yes & Yes \\
\hline Ukraine & Yes & No & Yes \\
\hline \multicolumn{4}{|l|}{ Latin America } \\
\hline Bolivia & No & Yes & Yes \\
\hline Chile & Yes & No & Yes \\
\hline Colombia & Yes & Yes & Yes \\
\hline El Salvador & No & No & Yes \\
\hline Mexico & Yes & Yes & Yes $^{1}$ \\
\hline Peru & Yes & Yes & Yes \\
\hline \multicolumn{4}{|l|}{ Middle East } \\
\hline Algeria & No & Yes & Yes \\
\hline Morocco & No & Yes & Yes \\
\hline Pakistan & Yes & Yes & Yes \\
\hline \multicolumn{4}{|l|}{ Other } \\
\hline Canada & Yes & No & Yes $^{1}$ \\
\hline New Zealand & Yes & No & Yes \\
\hline
\end{tabular}

Source: IMF survey.

${ }^{1}$ VAT and customs administration was, at the time of the survey, carried out by the same government entity. 